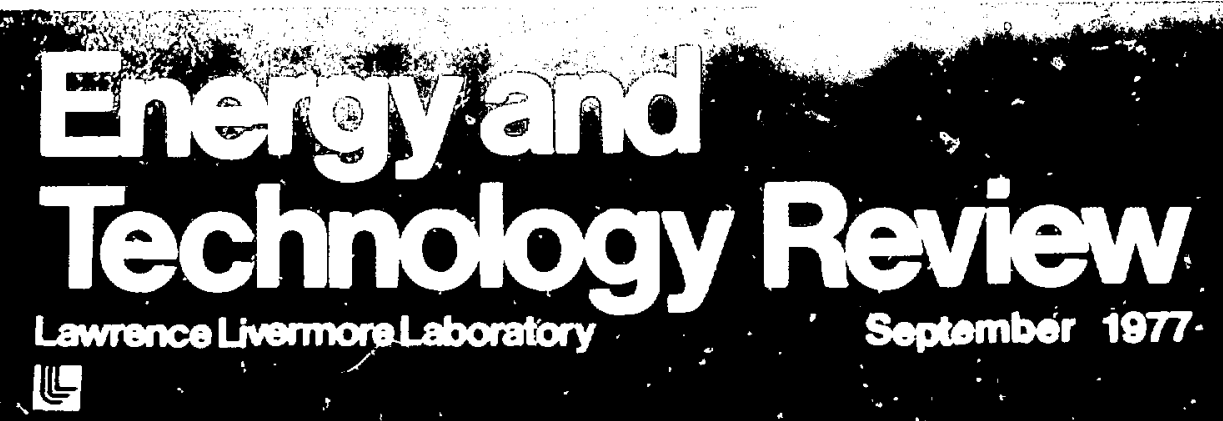




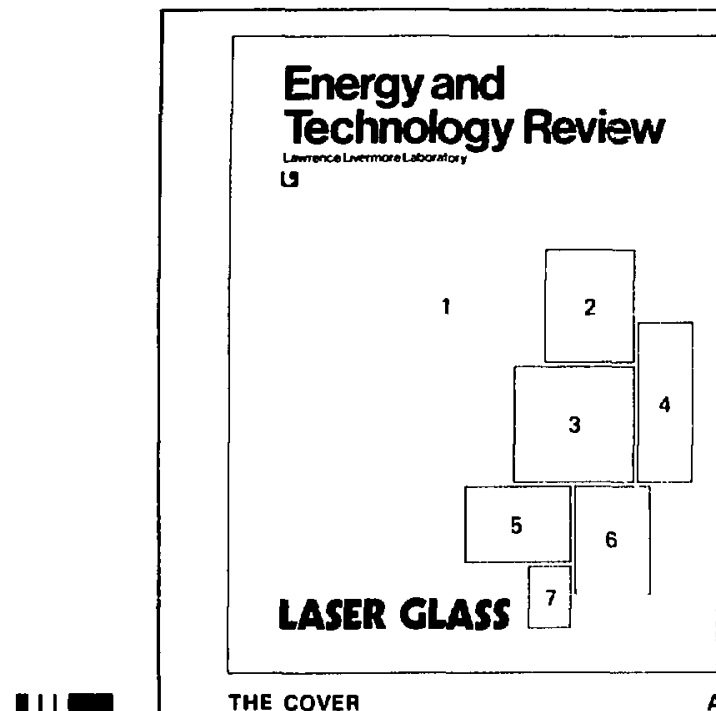

\section{THE COVER}

This photugraphic montage represents some of the research being done at LI.L to find taser glasses with opticul preperties ideal for highpower fusion lasers. These luser fusion systems require large optical elements (amplifier rods and disks, Ienses, windows, and larajay rotiturs) of high quility.

(I) $\wedge 20-\mathrm{cm}$ uperture lens used at the output of Shiva. These glasses must be immune to damage from intense laser beams and must hove a low nonlinear index of refraction to avoid sclf-focusing beam instabilities. The glasses used for amplification must ulso have high gain cuefficients. (2, 3, 4, and 7) Neodymium-doped amplifier disks and rods and Faraday rotator gliss. (5) $\wedge$ glass rod being inspected for imperfections. Note the tiny whitc dots, which indicate minute llaws in the gluss. (6) The interior of an amplifier module with a beam diameter of $20 \mathrm{~cm}$. The far end of the module is shown through several elljptical amplifier disks, each set at Brewster's angle to minimize reflection at the surface. Flashlumps. the long glass tubes surrounding the amplifier disks, optically pump these disks.

\section{ABOUT THE JOURNAL}

The Lawrente Livermore Laboratery is operated by the University of California for the United States lincrgy Rescarch and Development Administration. The Laboratury is one of two nuclear weapons de sign laboratories in the United States. Today neasly half of our effort is devoted to progtauns in magnetic and laser fusion energy, biumedical and environınental research, applied energy technolouy, and other research activities.

The Energy and Tecinology Review is published tnunthly to report on accomplishments in this energy and environmentul reseurch and on unclassified portions of the weapons program, $A$ companion journal, the Rezerch Monthy. reports on weapons research and other clnssified programs. Selected titles from past issues of the Energy and Techology Review are listed opposite the inside back cover. 


\section{Energy and Technolocy Review Lawrence Livermore Laboratory}

Prepared tor ERDA under contract No w.7405.Eng.48

Scientific Editor:

Henry D. Shay

General Editors.

A. Paul Adye Richard B. Crawford Brian D. Jarman Jane T. Sidehle
BRIEFS

Short items reporting on recent devclopments.

\section{NEUTRAL BEAMS FOR MAGNETIC FUSION}

High-energy, high-intensity neutral beams have been developed to tre point where they can heat plasmas to the thermonuclear temperatures needed in magnetic fusion reactors.

\section{MICROWAVE GAS ANALYZER DEVELOPMENT AT LLL}

We have developed a series of powerful instruments, based on microwave rotational spectroscopy, for detecting air pollution and analyzing its constituents.

\section{GLASSES FOR HIGH-POWER FUSION LASERS}

New fluoride-base glasses with low refractive indices will facilitate an early demonstration of the scientific feasibility of inertial confinement fusion.

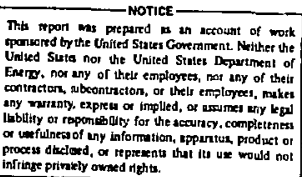
tponsered by the Cinited States Govemment. Nether the Uniled Suta not the United Stuler Departmeal of Eneras, nor any of thels emplayers, nost any of thetr contmetorn, abcontracton, or thelr emptoyes, nakes

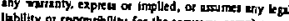

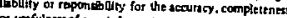
or ustulneca of eny information, Lppentas, product of process dtaclosd, or represents that ito ux would not instithe potriely owned nethts.

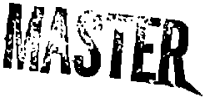




\section{MECHANICAL STHAIN EFFECTS IN LARGE MULTIFILAMENT SUPERCONDUCTORS}

f., . ace three vears we have heen conducing a

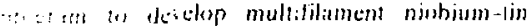
(?.). whislets fusson comlinement magnels. Althouph

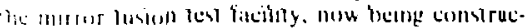

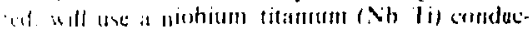

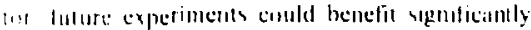
Itum the hagher manuete fields that are pessibic witlub, sin.

In the pist. large vibsin supercubulacting

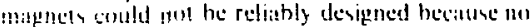
une knew exactly how the conducents would behave under mechaneal strạin. I he electrical perlormance

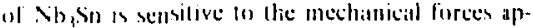
plicd during operation an a magne" lhe eritioal

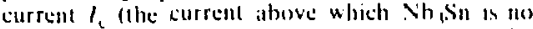
lenger at supereamdatore for specilic values of the magnetic fieid and temperature) is is rilpidly varying function of mechnieal stratin beciulse Nh ${ }_{3}$ Sn is very hrittle.

To cuantily anis effect and os learn how to make magnets of these conductors, we have constructed at large cryogenic tensile-test ipparatus. Its design permits iwo measurements: mechanicial properties al temperatures of 300 . 77. and $4.2 \mathrm{~K}$. ind critibal current values ufldei simulated operating conditions at $4.2 \mathrm{~K}$ as a function of serain and magnetic fietd. The maximum operating parameters of the mathine include loads of $22.3 \mathrm{kN}$, milgnetic fields of I2 T. and conducter currents of $10 \mathrm{k} \wedge$.

During the past year we tested a mumber of lange prototype conductors containing up to ahout $2590(x) \mathrm{Nb}_{3} \mathrm{~S}$ fillaments about $5 \mu \mathrm{m}$ in diameter. figure 1. hased on data collected from these tests. shows how $t_{c}$ varies with elongation. At lirst the critical curremt increases, apparently becaust the Iension relieves compressive stritins remaining in the miterial from the heat treatments it underwent during labrication. (t)or a diseussion of the fathricalion

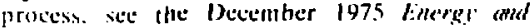

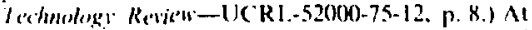
about 0.3" elongation the internal and external stratins become tequal, learing the conductor in an unstrained state and the eritical current all maximum.

These tests show that the eritical current in $\mathrm{Nb}$, Sn remitins it or above its initial value up to strains of $0.6^{\prime \prime}$. This fact implies that we can design

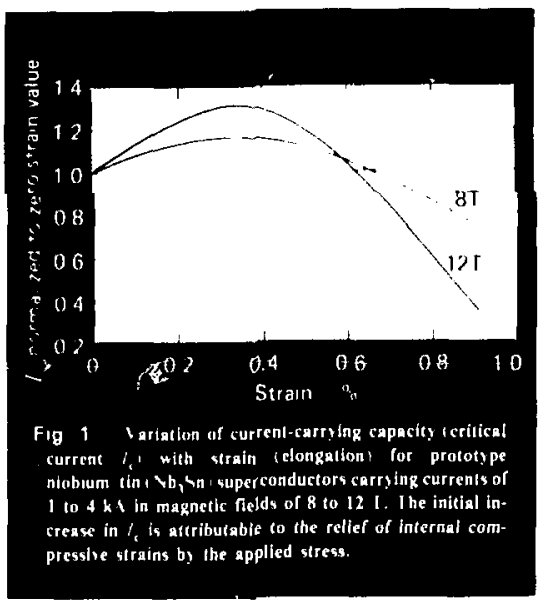

ind build Nh, Sin mignets with conventional struccural strain levels, as we do with Nb-Ti. Furthermore, large Nh fist conductors stretched as much ats $0 . x^{\prime \prime}$ eitn still recover apon reduction of the lond. This properly provides an important margin of salfety lrom irreversible damage.

He nos have enough data to hegin designing prolotype kest magnets of $\mathrm{Nb} 3 \mathrm{Sn}$. Successful completion of magnet testing, several yeats henee, would enable us lo design iarger fusion containment mitgenets operating all licelds up $1012 \mathrm{~J}$.

(untial I)aniel W. Deis (422-6715) for further inlormation on this subject. 


\section{ADVANCED ENERGY SYSTEMS}

\section{Neutral Beams for Magnetic Fusion}

Significant adsances in forming conergetic beams of neutral hydrogen and deuferium attoms have led to a breskthrough in magnetic fusion: neutral beams are nom heatiof plasman to thernonuclear tenperatures, lere al 1.1.1. atad at other laboratorics. For example. in our 2 XIIB evperiment иe hase injected a $5010-$ equivalent current of neutral deuterium atoins at an average energs of Is kol', producing a dense plasma $111^{14}$ particles/sm 3 at thermenuclear encrgy 14 ke' or 160 million kelsins). (urrently, I.I.I. and I.IHI. are deseloping beam energies in the 80- 10 120ke' range for our upeoming IIfly experiment, for the TITK tohamak experintent at l'rinceten, athd for the Doublet III tokamak experinient at Cieneral Atomic. These renulls increase our long-range prospects af producing hiph-intensity beans of energies in the hundreds or even thousands of kileelectron-solts, providing us with optinistic exerapolations for realiging poucr-producing fusion reactors.

The I aboratorts printipal lask in the natumal program for matenctic lusion is 11 develop the mignetic mirror approiath-one of several watys lo

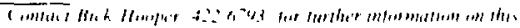
arinte'

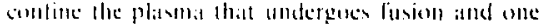

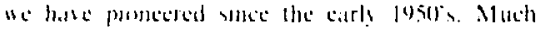

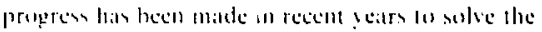
problem al confinme the plasma: the major problem of peoller.ting and heating the plasma is be. inge wolsed with neutral beams. Beatus of neulral

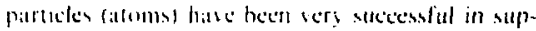
plsug and replaking particles and energy. Hecallse thes hatre no sharele ble? tress matentic liclds. llase are then iomied by collisions wilhin the plismat and hecome trapped in the mannetic lield. Veutral heims can also heall dorojdal confinement mathimes, but the particle energy reyuired lor penetration into the plasma is too high for supplying lual foms os these plismils.

We litst used neutral heams at the kilowatt level in the tlice experiment (which latler betame

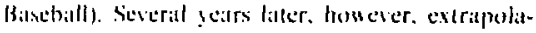
titi, of the requirements for our $2 \mathrm{X}$ experiment showed that a megawitl level would be needed to reach our experimental goals. As a result. the I as rence I aborallories (I ivermore and Berkeley) latunched an ellore to develop new beam systems. This ellore led first 10 beam modules that gave 10. A-equivilent ambunts at $1.5 \mathrm{keV}$ (average). then lu 5()-A-cyuivalent currents and energies of 20 to +10 kel: used in the 2Xll experiment. 'The tandem 
mirror experiment (TMX), ${ }^{2}$ under construction, will use beams similar to those of $2 X I 1$; the mirror fusion test facility (MFTF), ${ }^{3}$ also under construction will use $80-\mathrm{keV}$ beams. More recent developments ${ }^{4}$ have produced beams with peak energies of $120 \mathrm{keV}$. Long-range goals include intense beums at energies of hundreds and even thousands of kilo-electron-volts. This work and parallel efforts at the Oak Ridge National Laboratory and elsewhere in the world have resulted in a breakthrough in our ability to generate plasmas ut thermonuclear temperutures.
In this article we describe the physics of neutral beams. the state of beam development. and our joint (L.L1. and L.BL) research to produce beams of very high energy at high efficiency. LBL has had principal responsibility for the design, construction, and testing of the positive ion source. LLL assisted in this effort in engineering certain subassemblics-the extraction grids, for example-and in some pnases of the fabrication. The 2 XIIB facility at LL.L was, of course, the full-sis le application of these developments. LI.L has tokes the lead in developing negative ion sources. The high-voltage

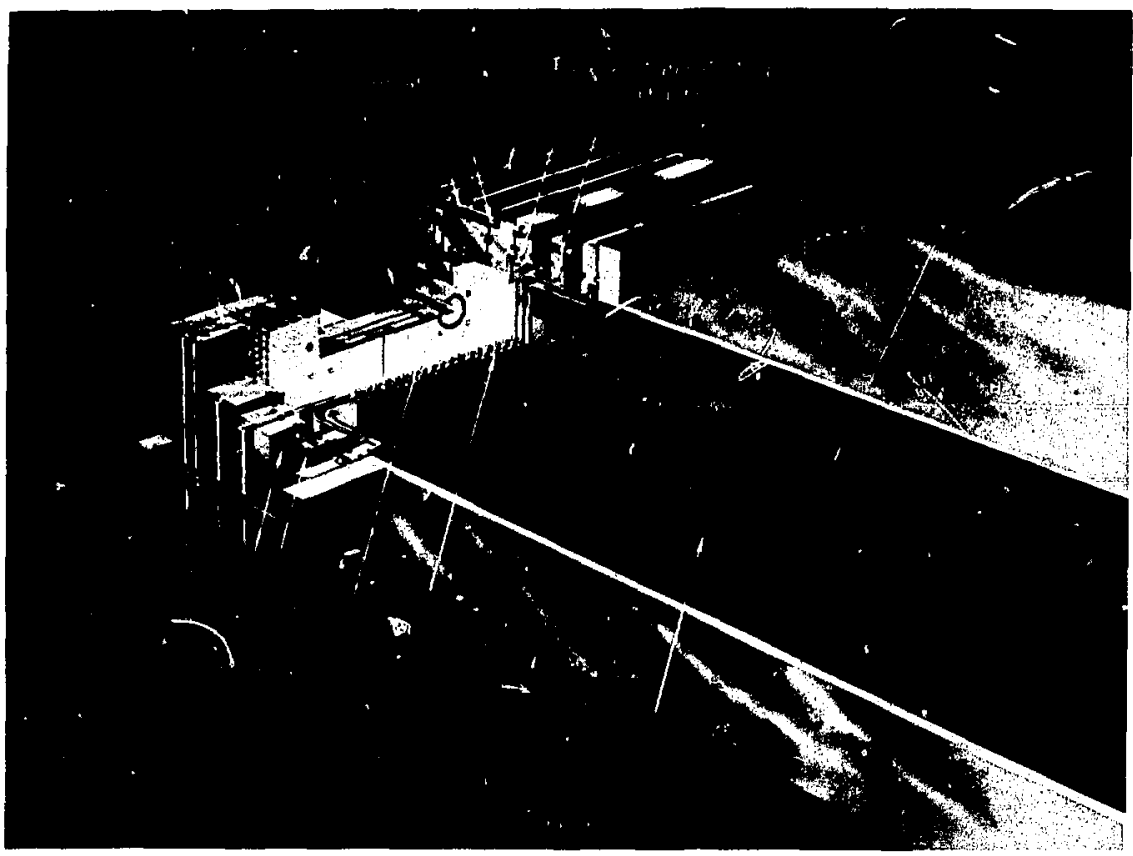

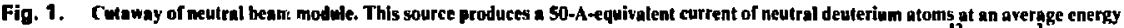
of $18 \mathrm{keV}$. The current drawn hetw een the filaments and the anode ionizes the deuterium gas to ahout $1 \%$, roughty $10^{12}$ jons/cm $/ \mathrm{cm}^{3}$. Positive iows and neutrals stream through defining accel-decel grids. Subsequent charge-exchange collisions between the positive lons and the deuterium gas result in a beam of neutral deulerion atoms having almost the full cnergy of the extrasted positive deuterium ions. The plasmg chamber is virtually free of magaetic fields, and the source plasma in the chamber is trec of insfabilit: and turbulence. The uniformity of this source plasma is one of the facters contributing to achicving the small angular divergence of the emitted beam. Tweive of these modules are used in the 2XIIB; 24 will be used in MFTF. 

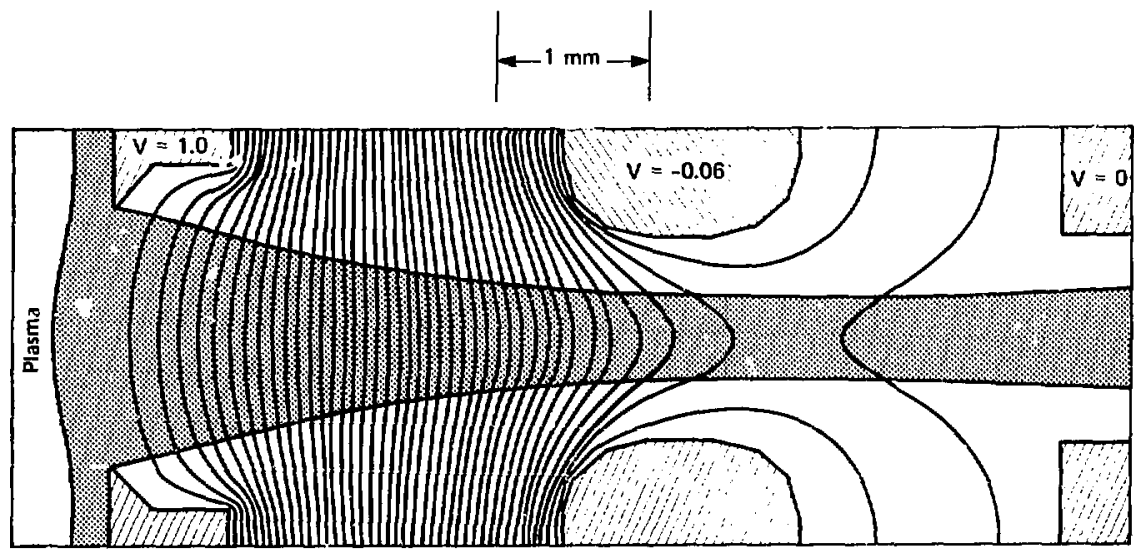

Fig. 2. Fifectric field potentials and envelope of lon Irujectories in the accolerating filds of the source illusitruted in likg. I. Voltakes are normalized to $20 \mathrm{keV}$. The extraction potential is, thus, $20 \mathrm{ket}$. The beani neutralizetion chamber is to the Icft. The cureful computer aptimization of the spacing and staping of these grids was eswential in achicving the small (about $1 \%$ ) ungular divergence of the enilted heam.

test stand is being constructed at LLL. for developing neutral beam sources based on both positive and negative ions.

\section{NEUTRAL BEAM FORMATION}

The first step in forming a neutral beam is to produce deuterium ions for subsequent acceleration by electric fields and eventual conversion to neutrals. This first step occurs in a plasma chamber or "arc box," such as the one shown in the neutral beam module illustrated in Fig. 1. An intense electrical discharge (typically $3500 \mathrm{~A}$ ), created by current drawn from hot tungsten filaments, ionizes about $1 \%$ of the deuterium gas-at $1.3 \mathrm{mPa}$ pressure ( $10 \mu$ Torr)-to form a plasma. The gas is injected through a gas inlet. Interactions in the plasma and on the chamber walls produce an ion minture of $75 \% \mathrm{D}^{+}$and $25 \% \mathrm{D}_{2}^{+}$and $\mathrm{D}_{3}^{+}$.

Ions from the plasma continually bombard the chamber walls. Some pass through slots of a grid mounied on the front wall and are accelerated by voltages applied between this and additional grids. A fraction of the ions is then converted intc neutral atoms through charge-exchanging collisions with the deuterium gas in the neutralized section. The resultant beam includes atoms at energies of the full accelerating potential (from $D^{+}$ions) as well as at one-half and one-third energies (from the $D_{2}^{+}$and $\mathrm{D}_{3}^{+}$jons. ${ }^{5}$ The fraction of ions converted to neutral atoms is high at low ion energies $(90 \%$ for deuterium at $20 \mathrm{keV}$ ), but at high energies (above $50 \mathrm{keV}$ ) it drops. Thus, at very high energies, a different technique will be required (discussed later).

\section{BEAM CRITERIA}

A neutral beam must satisfy several criteria to be effective. One is that beam power injected into the magnetically confined thermonuclear plasma must be as high as possible. Consequently, beam "optics" are critjcal. To a large extent, the optics are determined by the electric fields in the accelerating grids. The space charge in the extracted ion beam is high. necessitating computer analysis of the particle trajectories within the accelerator grids. Figure 2 shows a computer plot of the electric potentials and the envelope of ion trajectories within the grids of Fig. 1. The electrons in the arc box plasma are repelled by the applied eleciric potentials, which are 


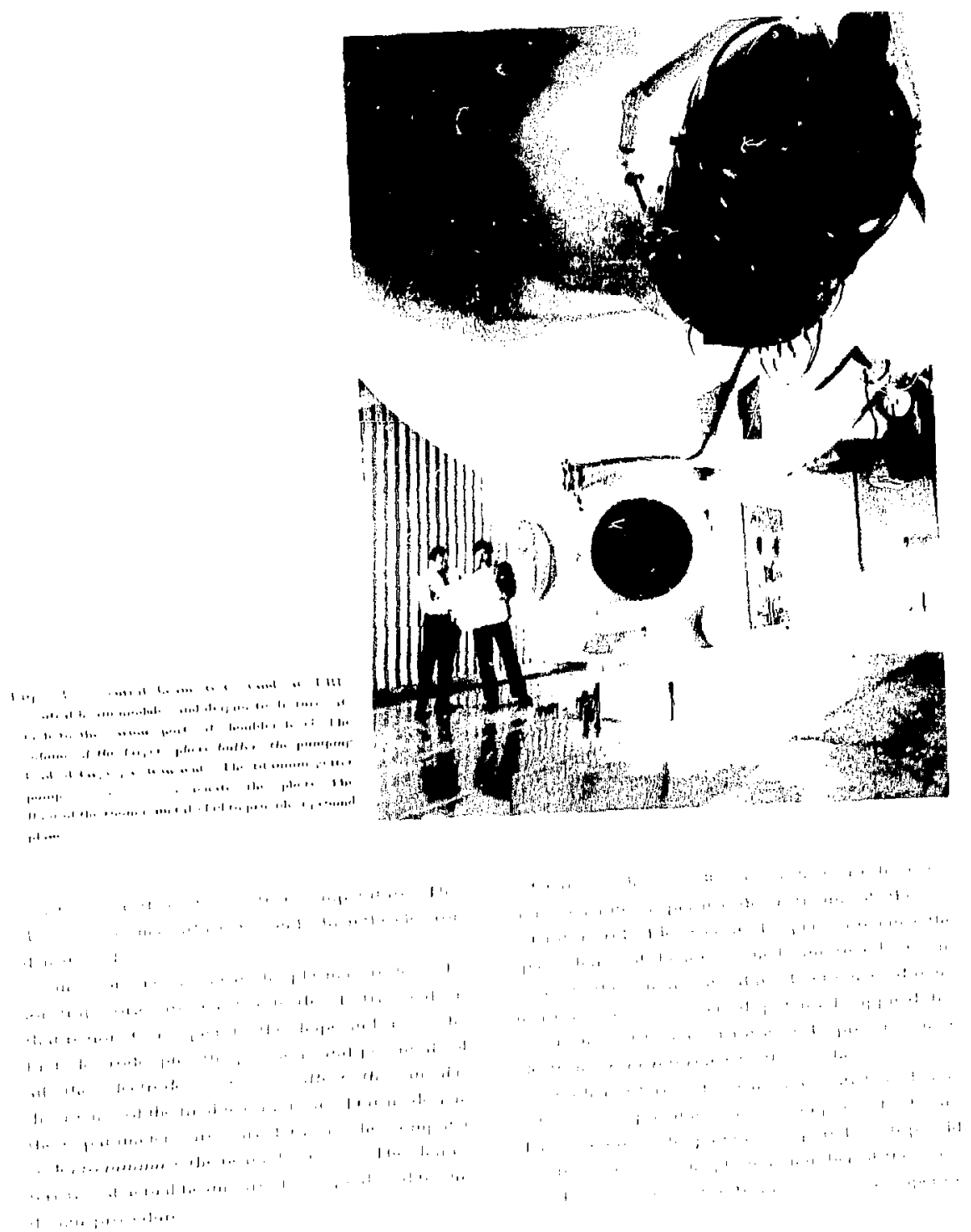



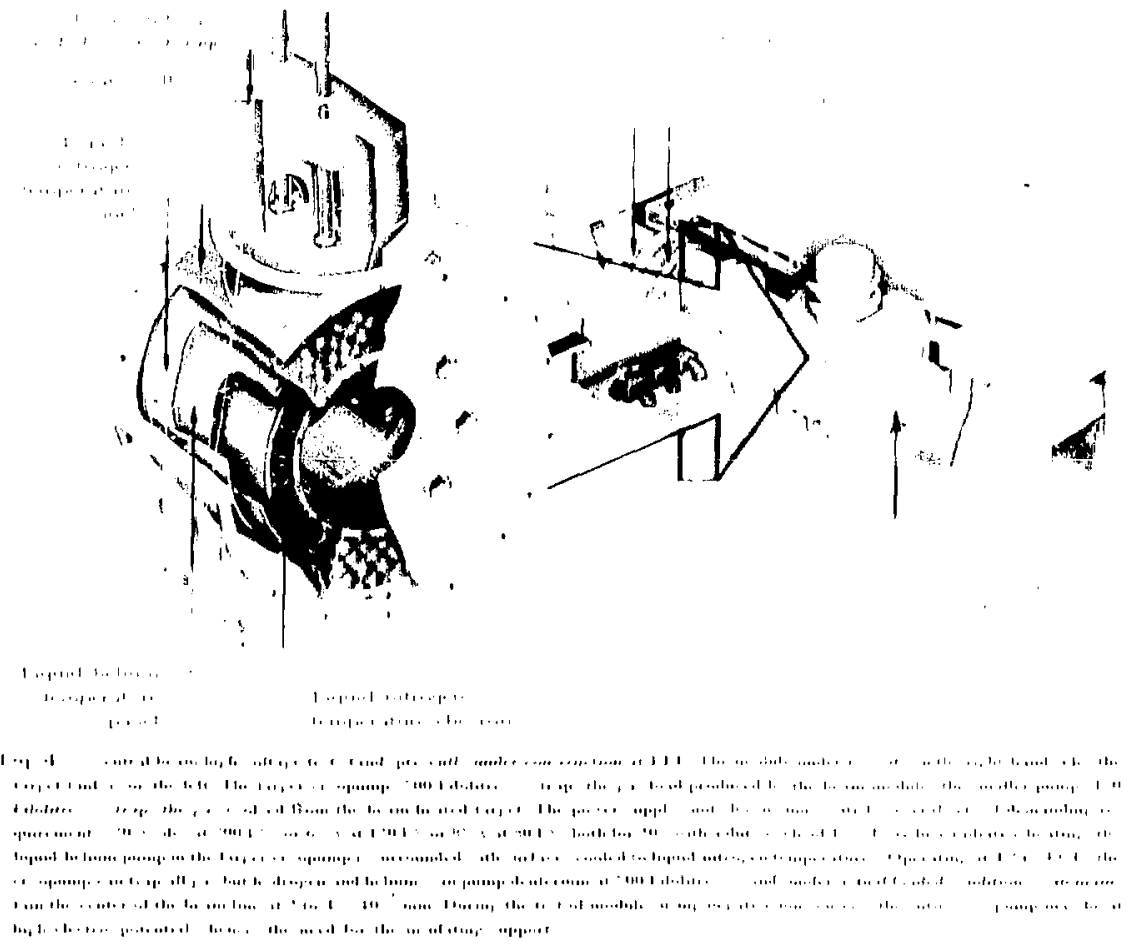

$11 \cdot 11 \ldots 11111 \cdot$

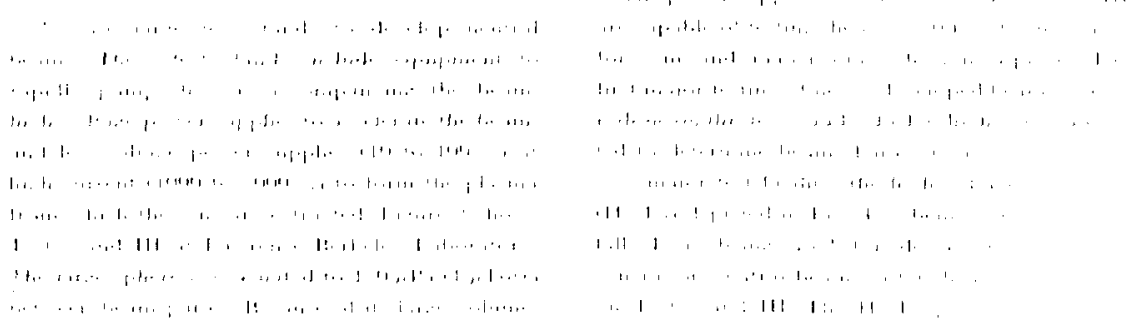


operate for long pulses ( $30 \mathrm{~s}$ and more) at energies as high as $200 \mathrm{keV}$. The outpui voltage can be either positive or negative, allowing it to be used in negative jon development, which we discuss later.

Deuterium beams striking a target saturated with deuterium are predicted to produce as many as $10^{12}$ neutrons/s, posing a serious radiation hazard. As it result, the HVTS beam line is located inside a roncrete-shielded room. The radiation level at the outside of the concrete walls will be less than the maximum permilted dose for personnel, even during the most intense beam operations. In contrust, our other test stands are not shielded and must use hydrogen instead of deuterium for high-voltuge, long-pulse operation.

In the HVTS, the deuterium gas accompanying the neutral beam is vaclium-pumped at $500 \mathrm{kl} / \mathrm{s}$ by a cryocondensation pump (Fig. 4). The gas freezes on panels cooled by liquid helium (al $4.2 \mathrm{~K}$ ). The helium, liquefied in an adjacent room, is confined to a closed-loop system to prevent losses to the almosphere. Heat ioading on the helium, especially by thermal radiation from room-temperature surfaces, is reduced by panels cooled to liquid-nitrogen temperature $(77 \mathrm{~K})$, as shown in Fig. 4. Also, the chevrons between the beam and the helium-cooled panels are cooled to $77 \mathrm{~K}$ to minimize heat loads.

Our test experience is being used to construct and test beam lines for mugnetic fusion experiments. For example, a joint LB! /LLL engineering teum is developing the beam line for use in the Princeton TFTR (toroidal fusion test reactor) tokamak. Also, LBL is developing the beam line for the Doublet III tokamak at General Atomic in San Diego. Buth

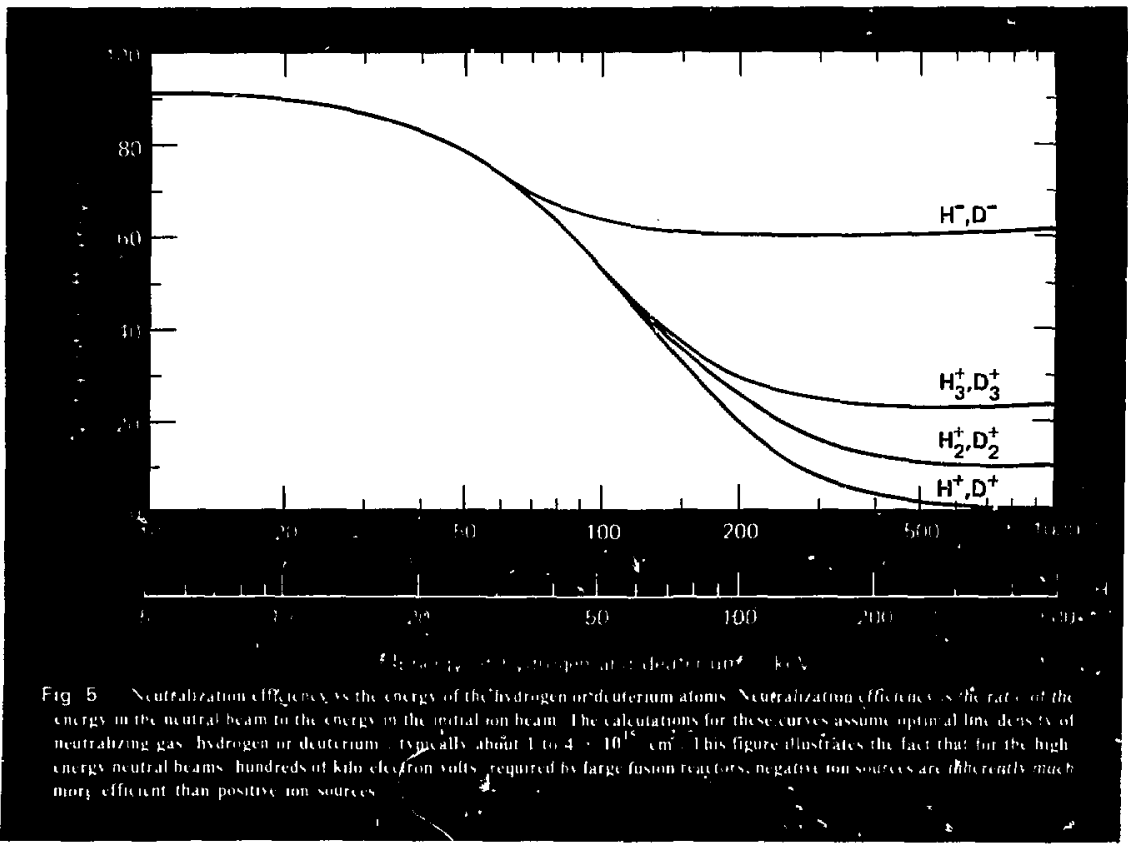




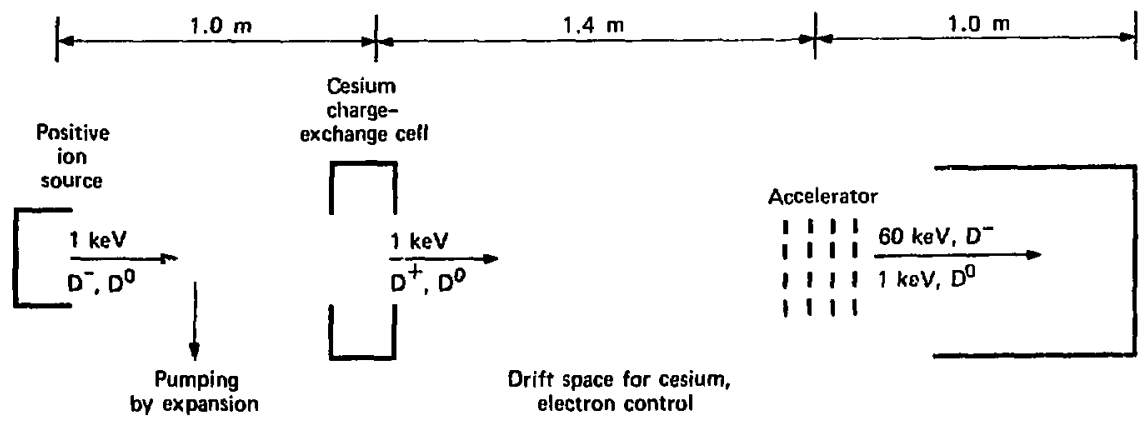

Fig. 6. Schematic of double charge-exchange experiment for producing high-energy $D^{-}$hezms. The powilive ion beam undergoes douhle charge exchange in the cexium vapor cell at relatively low energy-1 kev. The negatlve ion beam is then accelerated in the full encrey of 60 keV. This experiment has attained if ${ }^{-}$currents of 100 ma at 60 keV.

these lines incorporate many features of the HVTS neutral beam. Within L.LL, the beam development group also interacts with the mirror confinement group to provide the best neutral beams for the experiments.

\section{FUTURE DEVELOPMENT}

Neutral beams for thermonuclear reactors using magnetic fields are predicted to require energies in the range of $200 \mathrm{keV}$ to $: .2 \mathrm{MeV}$. As mentioned earlier, charge-exthange efficiencies are small at high ion tinergies, so that most of the accelerated power remains in the ion part of the beam. This limitation will be overcome by using the high efficiency with which an electron can be stripped from a negative ion. ${ }^{6}$ As illustrated in Fig. 5, the neutralization efficiency at high energies is at least three times more efficient for stripping negatively charged hydrogen or deuterium iors than for charge exchange on positive ions. We are therefore working on the advanced development of netural beams based on negative ions instead of positive ions-neutratizing the ion by stripping rather than by charge exchange.

The neutralization efficiency for negative ions can be made larger than that indicated in Fig. 5 by stripping the beam in a highly ionized plasma. Efticien- cies greater than $80 \%$ can be attained. Ultimately, efficiencies close to $100 \%$ may be reached with stripping by ligbt: if the energy of the photons is greater than the $0.75-\mathrm{eV}$ binding energy of the extra electron on the deuterium ion. photon-ion collisions can remove the electron. Such stripping will require high-efficiency lasers and a high-quality optical cavity to keep the power required to produce the laser beam acceptably luw.

The most difficult part of this development is to produce high-energy negative deuterium ions. Scveral production techniques are being studied at LLL and elsewhere. The technique we are studying the mosi intensely is charge exchange in cesium vapor:

$$
\mathrm{D}+\mathrm{Cs} \rightarrow \mathrm{D}^{-}+\mathrm{Cs}+
$$

The efficiency of this process is $24 \%$ at $1 \mathrm{keV}$ and even greater at lower ion energies.

In this technique ${ }^{7}$ a $^{+}$beam produced, for example, at I keV passes through cesium vapor (Fig. o). Resultant collisions rapidly convert the beam to $\mathrm{D}^{0}$. Further collisions with the cesium convert $20 \%$ or more of the $\mathrm{D}^{0}$ to $\mathrm{D}^{-}$; thus. the process is often culled double charge exchange. The beam then travels through a drift space, where the density of the desterium gas accompanying the beam is 
reduced to a relatively low level. This space is also used to control electrons, since any electrons in the beam are also accelerated, thereby reducing the production efficiency of the final, high-energy beam. In the drift space, the random kinetic energy of any elections carties them away from the beam, leaving a beam whose space charge is neutralized by background positive ions. At the time of writing, a current of about $100 \mathrm{~mA}$ of negative deuterium ions had been accelcrated to $60 \mathrm{keV}$. We plan to develop a larger system that will provide $1 \mathrm{MW}$ of $\mathrm{D}^{0}$ at 200 keV-a major step in the development of highenergy neutral heims for experiments and reaclors.

Ney Words: highesnurgy Mowlrol beoms; ton biams; magnutic fisfoH: magnetic mirrors; Heutral beams.

\section{NOTES AND REFERENCES}

1. For an overview of the LLL magnetic fusion energy program and a description of the 2XII experiment, see the June 1976 Finergy and Technology Review (UCRL-S2000-76-6), p. 1.

2. The TMX experiment is described in the July 1977 Euserg' and Technology Review (UCRL-52000-77-7), p. I.

3. For a description of the MFTF experiment, see A Alirror an Energy, Lawrence Livermore Laboratory, Brochure B-090 (May 1977).

4. For fusther information, see K. W. Ehlens, K. H. Berkner, W. S. Cooper, J. M. Haughian, W. B. Kunkel, B. A. Prichard. Jr., R. V. Pyle, and J. W. Stearns in Procectings 9th Symposium on Fusion Technology, Garmisch, W. Germany. June 1976; also available us Lawrence Berkeley Laboratory, Repl. LBL-4471 (1976).

5. For detrils on neutralization elficiencies, see K. H. Berkner. R, V. Pylc, and J. W. Stearns, Nuclear Fution 15, 249 ( I975).

6. A general discussion of high-efficiency beams was presented by E. B. Hooper, Jr.; at the Intermational School of Plasma Physics: Third Sympasium an Plasma Heasing in Toroidal Devices. Varenna. Iraly, September 1976; utso avilable as Lawrence Livermore Laboratory, Rept. UCRL-78623 (1976).

7. The current status of this experiment was reported by E. B. Hooper. Jr., O. A. Anderson, T. J. Orzechowski, and P. Poulsen at the Symposiunt on Negative Ion Beams. Brookhaven National Laboratory, Upton, New York, September 1977; also available os Lawrence Livermore Laboratory, Rept. UCRL-80102 (1977). 


\section{ENVIRONMENT AND SAFETY \\ Microwave Gas Analyzer Development at LLL}

Air-pollution control efforts have long been hampered by the need for adequate instrumentation. Since the mid-1960's, LLL has worked to fll this need, developing an increasingly more sophisticated series of monitors, detectors, and gas analyzers based on microwave spectroscopy. One of our instruments has achieved unprecedented seusitivity, detecting (on a cycle of four data poiats per howr) less than $1 \mathrm{ppb}$ of ammonia in air. Apother continuously measures ammonia in the range 200 to $1000 \mathrm{pph}$ in our Imperial Valley environmental survey. A recent development is a monitor that is specifically sensitive only to vater vapor. Another instrument, considerably less specialized, will measure any of 10 common hazardous solvents iu concentrations as low os one-fifth of safe occupational limits. Future developments now in the planning stage include an inexpensive processcontrol monitor to continuously analyze the products of a chemical reaction and a hand-held personal monitor to check for Jocal hazards such as carbon momoxite.

Cantact Lawrence $\boldsymbol{W}$. Hrubesh (122-6385) for further information on this article.
Inadequate instrumentation is a difficulty that has plagued air-pollution control efforts since their inception. Existing methods for measuring many of the irritants and poisons in the air have been cum. bersome and nautomated, relying on bulky equipment and time-consuming procedures. Samples are collected in the field, carried to a laboratory, and analyzed by chemical methods. By the time analysis is completed, much environmental damage may already have taken place.

To overcome this difficulty, LLL has developed a series of instruments based on microwave rotational spectroscopy. These instruments can cope with the detection and analysis problems associated with a wide variety of pollutants and the extremely small, yet significant, concentrations in which these pollutants may occur.

The potential of microwave rotational spectroscopy for chemical analysis was recognized early. This potential, however, was not realized until the late 1960's when commercial instruments became; available. In the mid-1960's we set out to produce microwave instrumentation with optimum sensitivity that could search for spectral information 
from transient species within a complex gus mixtt: e during fast chemical reactions. We developed a very sensilive search spectrometer having a resonant cavity as the absorption cell ' and used it to detect transients such as $\mathrm{OH}$ and $\mathrm{Nr}_{2}$ in reactive mixtures. $^{2}$

A major technological advance in microwave

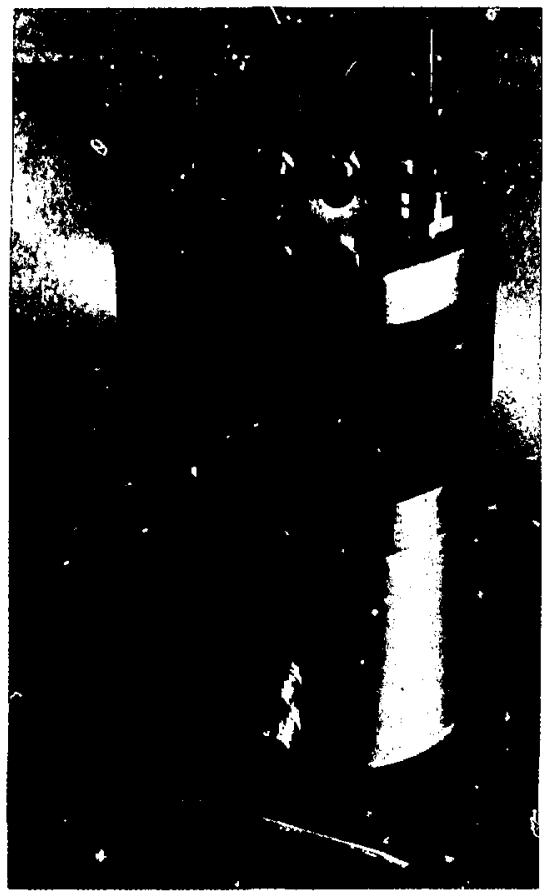

Fig. 1. The absorption cell of a typleal microwave rotational spectrometer. The mper portion between the two flanges is the resonan cavily surroumded by a heater (biack band): the lower pertion is a howsing for some of the associated electronics. The heater varies the kength of the cavity by thermal expansion. thereby combrolling its resonnt frequency. In one of the rectangelar bocks on the top flange there is a tiny (iunn diode for producing the microwaves. The other block houses a differen kivi of diokle for detecting them. The iwo stainless-steel fittings are vacuen cennectlons, one to the vincunn pump and one to the device for a sitting the gas semple. generation occurred when (junn-effect diodes came on the market. Ciunn diodes are small, low-power, solid-state microwave generators whose output frequency is eabily cuned and stabilized. They quickly replaced large high-voltage vacuum tubes as reliable excitation sources for microwave rotational spectrosciopy.

Soon after the ciunn diodes became available we demonstrated a simple. sensitive. and compact spectrometer ${ }^{3}$ which combined the diode with a small resoninl cavity (fig. 1). Various ageneies concerned with envirommental monitoring, recognizing the possibility of incorporating such a device into a portable gats analyaer, commissiuned us to develop prolotype instruments for specific gases. The microuave technique was particularly exciting heciuse it offered ihe high resolution needed to determine unambiguously the kinds and amoun wo of pollutants in the atmosphere.

\section{OPEAATION}

A mierowave spectrometer consists basically of three main components: a microwave radiation sourec, an absorption cell in which to expose the gas to microwave radiation, and a microwave detector (Fig. 2). The source radiates microwaves at a constant pewer level, and the delector records the amount of microwaves not absorbed by the gas. The absorption is strongly dependent on frequency; tuning the souree through a frequency range produces a series of sharp, well-separated dips in the detector output, a microwave absorption spectrum that is unir,ucly characteristic of the gas in the absorption cell. Figure 3 is part of the microwave absorption spectrum for methanol,

The widths of the absorption dips depend on the gas pressure in the atsorption cell: at ordinary pressures the dips become so broad and shallow as to be undetectable. Practical spectrometers. therefore, operate at pressures of $30 \mathrm{~Pa}(230 \mu \mathrm{m} \mathrm{Hg})$ or less. In our system a vacuum pump maintains the low pressure, and the injection cell supplies the analysis gas at a rate compatible with the pump's speed.

This system employs a modulated input signal and a narrow-band, phase-sensitive (lock-in- 


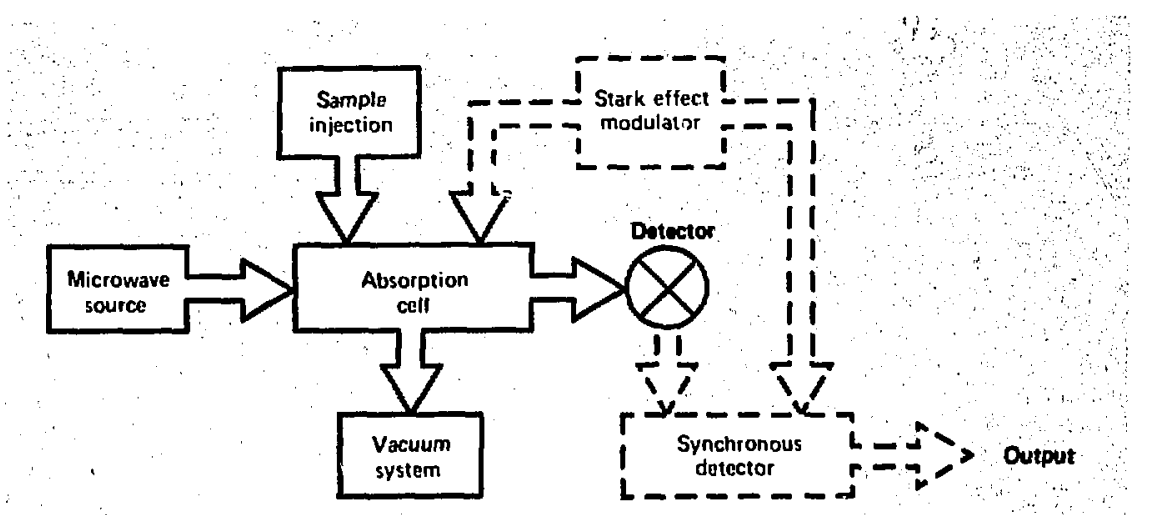

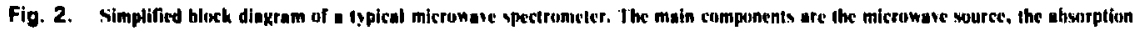

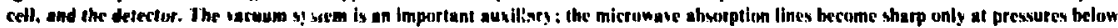

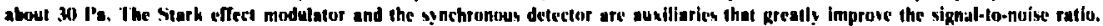

amplifier) detector to improve the signal-to-noise contrast. A passive detector whose output depends only on the incoming signal gives a constant signal for a constant input. Direct-current signals are hard to amplify: random nuctuations, which occur on any signal and are easy to amplify, grow out of proportion and obscure the absorption lines. To circumvent this difficulty, the incoming signal is chopped into a series of pulses, typically at over $5 \mathrm{kHz}$. The detector amplifier is specially tuned to this modulation frequency. The random fluctuations are small in compirison to the difference between signal on and signal off, and the result is a greatly improved signal-to-noise ratio.

Signal chopping is accomplished by applying a pulsed electric field across the gas in the absorption cell, where the Stark effect changes the absorption spectrum of the gas, splitting each sharp spectral line into a number of weak ones that appear only when the electric fieid is on. Between pulses the absorption spectrum remains normal. Above the baseline the detector displays absorption lines that are in phase with the pulsed elestric field; below the baseline are displayed only those lines that appear when the electric field is off (the normal spectrum). Figure 3 was produced in this way and shows both kinds of lines.

Gunn diodes and other microwave oscillators generate highly monochromatic radiation in the frequency range 3 to $300 \mathrm{GHz}$, corresponding to wavelengths of 100 to $1 \mathrm{~mm}$. Optical spectroscopy deals with infrared, visible, or ultraviolet light; prisms, gratings, mirrors, and slits are used for analyzing the wavelengths present and observing absorption lines. Microwave radiation, on the other hand, is transmitted through circular or rectangular waveguides and analyzed by electronic techniques. In some spectrometers the waveguide doubles as the absorption cell.

In a waveguide absorption cell the microwave radiation passes through the gas only once; the waveguide must therefore be long to give measurable absorption. For compactness our spectrometer uses a resonant cavity for the absorption cell. Herc, the microwave radiation reflects back and forth many times, multiplying the amount of radiation absorbed.

As in ultraviolet, visible, or infrared spec- 


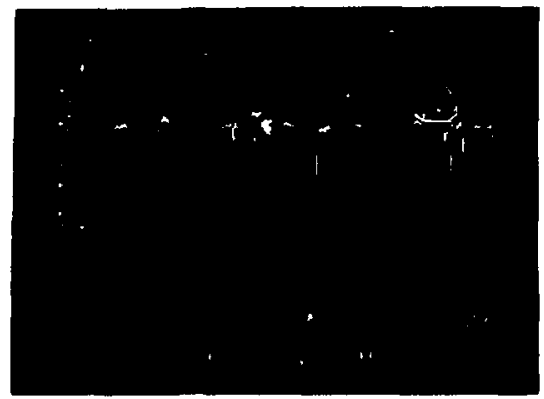

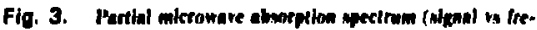
queacy f for methanot, showing the sharp resonances (downward dips) characteriule of pure tofational pectra. 'Ithe peaks ahove the baseline are artifacts of the stark efiect; the signal is procesued to display then above the lise to prevent theit bejng confused with the normal specirum lieses. This small and easily Igaured dislortion of the baseline is a small price to pay for the vase improvemeat in the signal-to-nolue ratio resulting from signal modulation by the Stark effect.

troscopy, the microwave absorption spectrum arises from Iransitions between energy levels. The frequency at which the absorption takes place corresponds to the energy difference between two states. The mechanisms that cause the four spectra, however, differ. Ultraviolet and visible spectra arise from transitions between electronic encrgy levels. infrared spectra arise from transitions between molecular vibrational energy levels, and microwave spectra arise from transitions between molecular rotational energy levels.

The rotational motion of molecules in the gas phase is quantized into discrete states with sharply defined energy values. The energy difference between rotational states is slight compared to the vibrational energy. Thus, many rotational states are populated at normal temperatures. Because the spectral lines can be made very narrow at low enough pressures (typically having a full width at half maximum of 0.00002 wavenumbers at pressures of $30 \mathrm{~Pa}$ ) and because the microwave radiation is coherent. monochromatic, and tunable, no other present form of molecular spectroscopy has a higher resolution than microwave rotational spectroscory.

\section{DEVELOPMENT AT LLL}

In 1973 existing we':-chemical analytical methods showed that formaldehyde is a major constituent of automobile exhausts and also that it is virtually absent in the air. even in cities. Evidently the formaldehyde is destroyed soon after it leaves the tailpipe, but the 1973 methods were unable to trace the course or identify the products of the reactions. For this reason the Environmental Protection Agency was secking an analytical instrument not only sensitive enough to detect very small quantities of gases but also simple to use, reliahle, and portabls. Microwave speetroseopy was attratetive because it is stelcetive; its output is unaffected by in. terfering gatses. ${ }^{4} \mathrm{Also}$, combining miniature solidstate diodes with sinall but highly eflective resoniant cavities made simple. portable instrumentition feasible.

The prototype instrument. " which we completed and delivered to the Invironmental Protection Agency in 1974, was only parlly suceessful. Although its selectivity and accuracy were much better than those of the wet-chemistry methods for analyzing exhaust simples. its sensitivity of about $500 \mathrm{pph}$ was inadequate for ambient air measure-

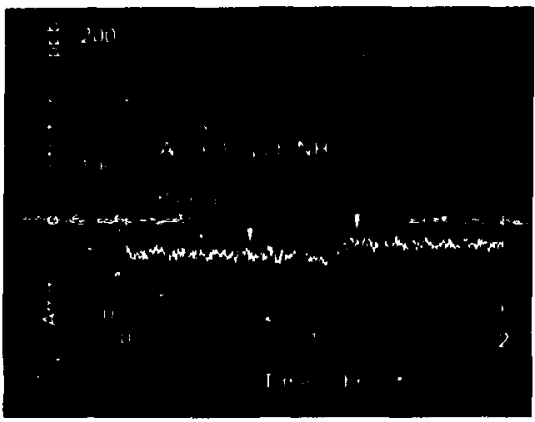

Fig. 4. Pen recorier trace showing the response of a microware ammonis monitor to the addition of a trace of ammonia (about 10 pph) to the air belig sumpled. Is this mode the microwave spectrometer is cyerated on a fixed frequency corresponding to one of the major a'osorption lincs of ammonin. The signal controlling the recorder pen Is made proportional to the deviation of the mictowave sigual from its full (nomabsorbed) strength. 


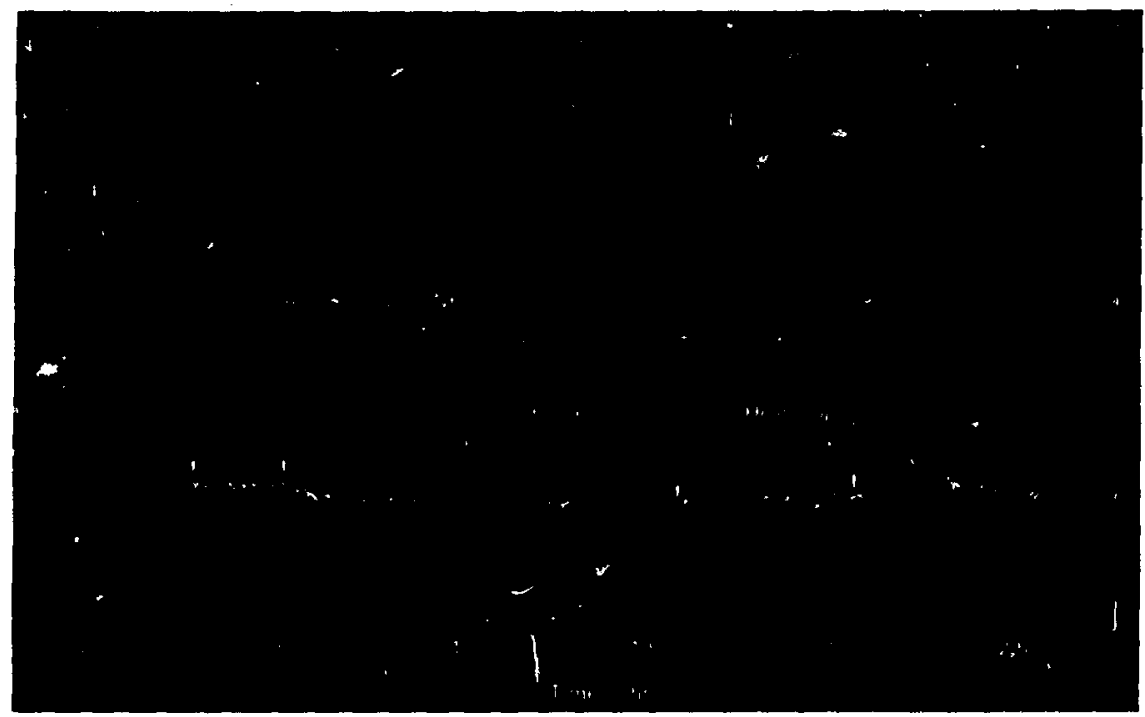

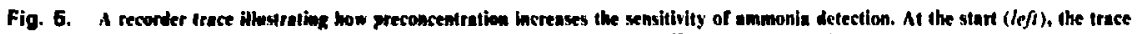
shows the detector response to 500 mof of monin without preconcentration. When the flow is diverted to pass through the trap, the response drops escentinly to zero. After accumulating for about an hour, the ammonis begins to kesk out (breakthrough). Heating the trap releases the accunulated anmonin. causing arme detector response. By this means it is possible to detecl ammonin traces as low es 0.8 ppb.

ments. Since formaldehyde in exhaust is currently only of research interest, the market for such a formaldehyde monitor is inadequate to attract a commercial manufacturer.

Our next such instrument, an ammonia-vapor monitor for the California Air Resources Board. was much more satisfactory. We designed a membrane prefilter into the instrument: the prefilter selectively admits ammonia to the vacuum system while holding back most of the other constituents of the sample. boosting the instrument sensitivity to better than $50 \mathrm{ppb}$ of ammonia in ambient air. This is the highest sensitivity ever achieved for coninuous detection of any gas by microwave spectroscopy. Figure 4 shows how the output of this monitor responds to the addition of $10 \mathrm{ppb}$ of ammonia to a stream of pure air.

Near the end of our prototype ammonia-monitor development the Environmental Protection Agency, which had been following our work, requested that we try to extend the instrument's sensitivity to I ppb or below. This problem was solved by designing a modular attachment that automatically preconcentrates the sample, trapping the ammonia on a special chromatograpinic material (Chromosorb 104) for 10 minutes and then releasing it to the microwave absorption chamber in a burst. ${ }^{6}$ Figure 5 illustrutes one operating cycle of this monitor. Although its operation is thus intermittent, the instrument can detect as little as $0.8 \mathrm{ppb}$ of ammonia in a lahoratory-prepared sample. It is now being tested by both the California Air Resources Board and the Environmental Protection Agency, and it may be adopted as a standard method for trace ammonia detection in air.

Meanwhile, the ammonia-vapor monitor has 


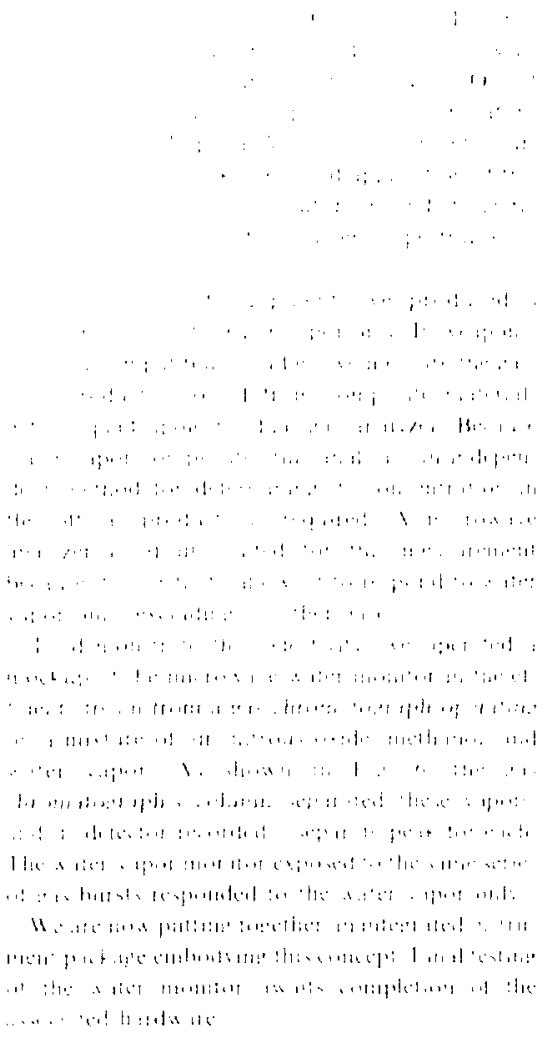

\section{(WIRKNT AND FUTURE DEVELOPMENTS}

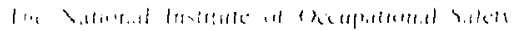

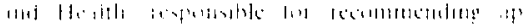

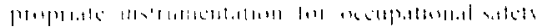

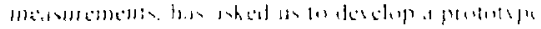

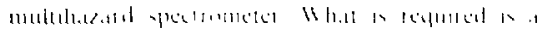

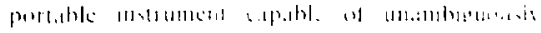

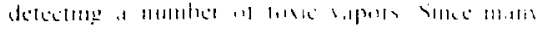

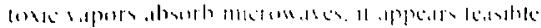

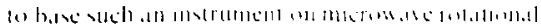

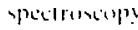

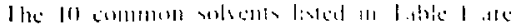

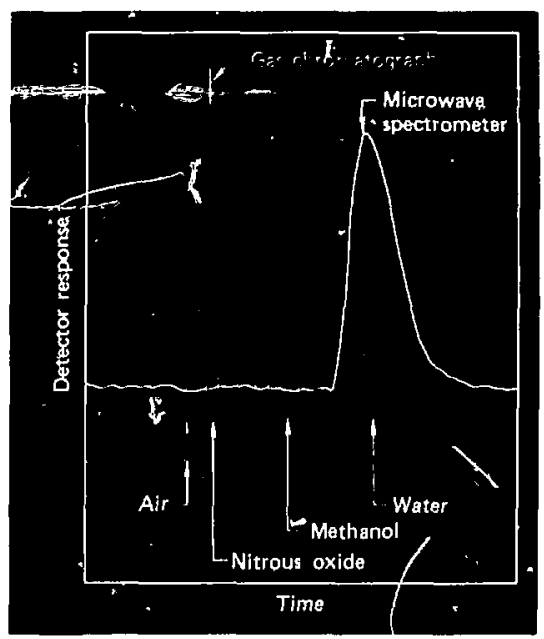

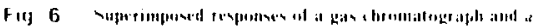

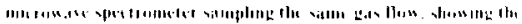

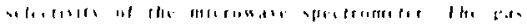

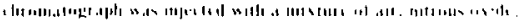

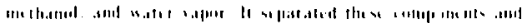

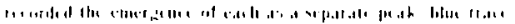

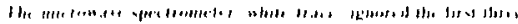
a als

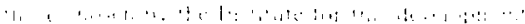

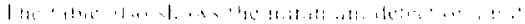

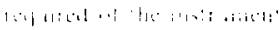

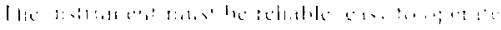
11 1 ;

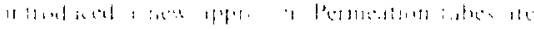

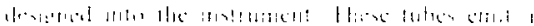

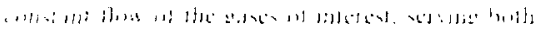

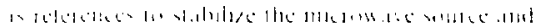

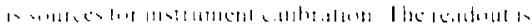

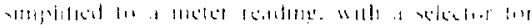

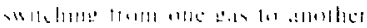

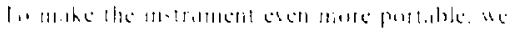

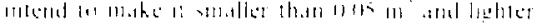

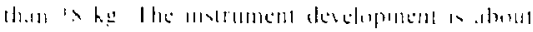

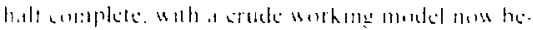

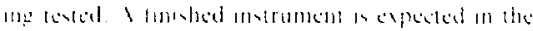
prille $110 \%$ 


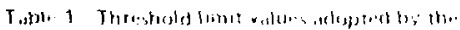

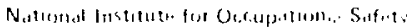

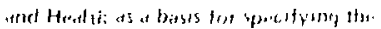

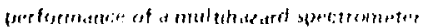

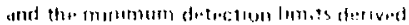

trom the...

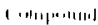

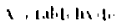

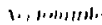

B., J, II,

ItIII)in.1

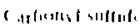

f chisetet?

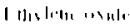

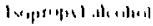

M. Ihinat

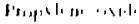

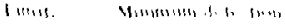

PPIs

hIIII. flen

(1)

$? 16$

11)

[11) (1)

3

all

|S AN |

.11

आ111

गा11

1911

n

?111

$\checkmark$

1.

$\therefore$ III

(t)

an

[II

?I) 


\section{NATIONAL SECURITY \\ Glasses for High-Power Fusion Lasers}

Neodymium-doped glass lasers, such as those in 1.L.L's Shiva laser system, offer the best chance for carly demonstration of the scientific feasibility of inertial confinement fusion. The output of these highpower lasers is determined by the media used for their amplifying and transmitting components. Our research has shewn that significant increases in performance are possible with new luoride-base glasses that have low refractive indices. These new glasses form the basis for more powerful experimental solidstate lasers and are potentially useful for advanced fusion laser systems.

A means for the practical conversion of nuclear power to electrical power may be by inertial confinement fusion. We anticipate that the earliest demonstration of the scientific feasibility of this concept will be by means of laser-induced implosion of D-T pellets. In the past few years, considerable progress has been made in the development of powerful laser systems capable of igniting evcrincreasing quantities of inertially confined nuclear fuel. ' The most advanced lasers for this purpose use

Confact Marvin J. Weher (422-5486) for further information on this anicle. 
Fig. 1. Fasion Inser anelifiers. The amplirying mediun is acadywime-loped sllsate glase ( Top) Rod ampliner. The laser rod is $5 \mathrm{~cm}$ in dianeter and b surrounded by an array of xewon Rashlamp that serve as the optlcal pump. (Bottom) Disk a... plities. The ellipiteal laser disks are $15 \times 30 \times 3$ co. and are oricated at Brewuer's angle to minimize reflectlons.
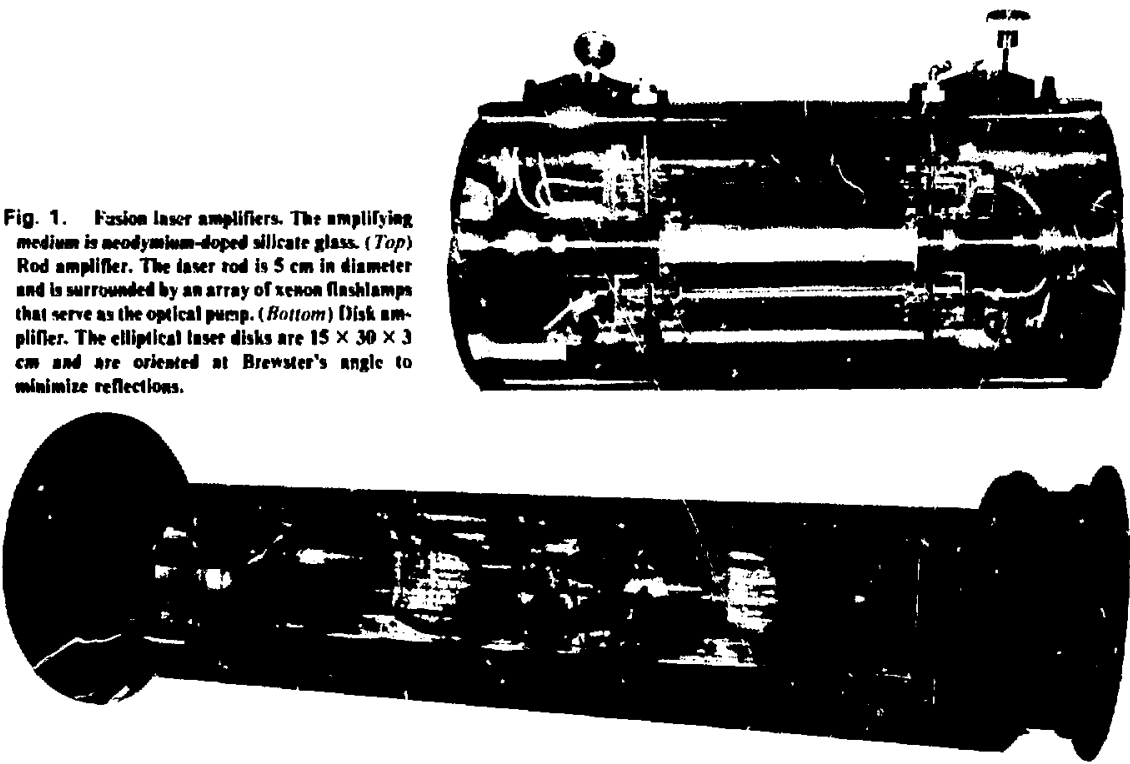

neodymium-doped glass as the amplifying modium. Typical rod and disk amplifiers are shown in Fig. 1. These components are arranged in chains of increasing apertures as shown in Fig. 2. The resulting systems are able to concentrate many terawatts of optical power onto targets of less than a millimetre in times of less than a nanosecond.

It became apparent at an early stage in the glass laser development program at LLL that future fusion laser development would be limited by the properties of the laser optics. Lasers based on both Nd-glass amplifier media, as well as gas amplifier media, use glass and crystalline optical materials extensively. The nonlinear propagation properties, the damage levels, and the ease of manufacture of largeaperture optics define the performance of all of these systems. In the case of Nd-glass laser systems, additional attention must be paid to the lasing properties of the glass amplifier media. When we began to study the effect that glass lasing properties and nonlinear propagation properties had on system performance, we found that remarkable increases in laser system performance were available if materials with high gain and low nonlineur refraction index could be found. These properties have now been realized with the fabrication of large pieces of fluoride-base laser glass. These micerials have permitted us to extend our solid-state laser designs from the 30-TW Shiva laser to the 200- to 300-TW Nova laser and to conceive of a 1000-TW solid.state reactor-test laser.

Glass is used in several laser components. ${ }^{2}$ The primary use is for the amplifying components-presently silicate glass with neodymium dopant. Glass is a!so used for light-transmitting components (such as lenses, windows, and substrates for thin-film polarizers and beam splitters) and for Faraday rotation in optical isolators. For laser beam diameters up to $50 \mathrm{~cm}$, glass is an attractive medium since it can be made in large sizes with the requisite high optical quality; in fact, a limiting size for glass components has not been reached. 

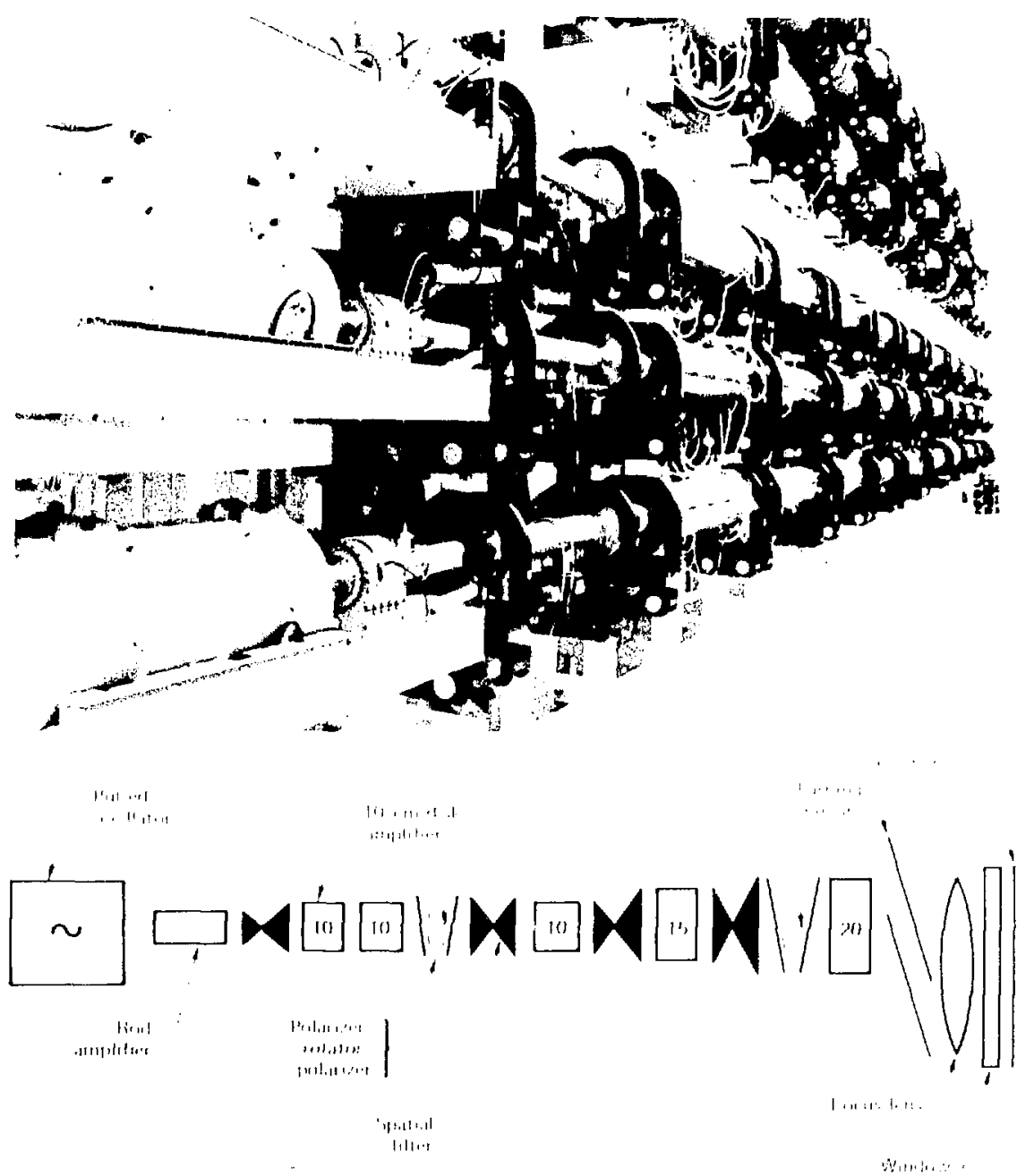

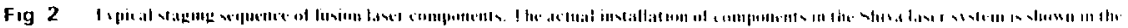

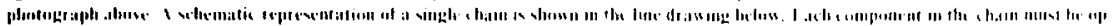

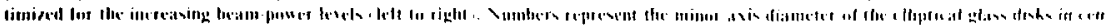

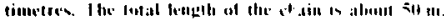




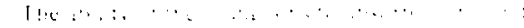

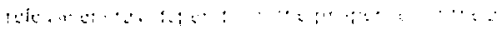

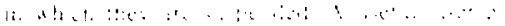

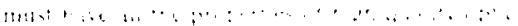

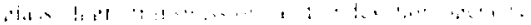

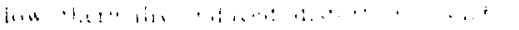

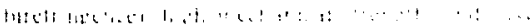

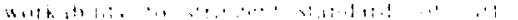

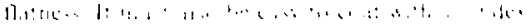

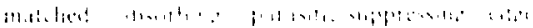

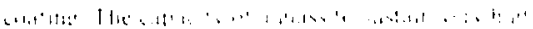

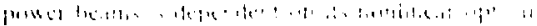

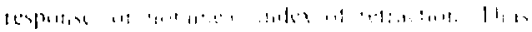

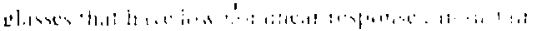

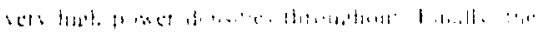

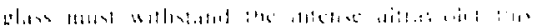

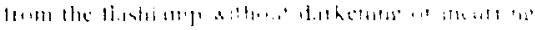

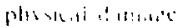

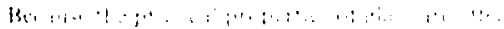

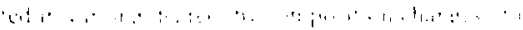

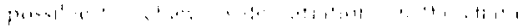

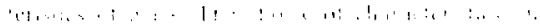

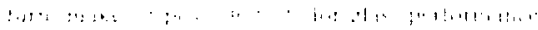

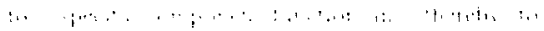

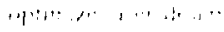

\section{IASI B GIIASS I:B SI AFGiH PRORERAM}

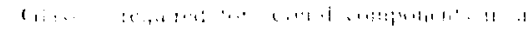

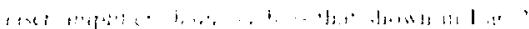

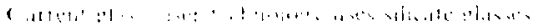

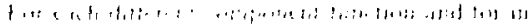

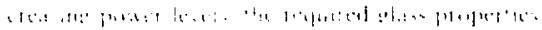

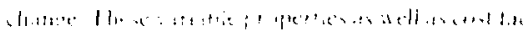

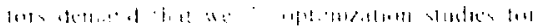

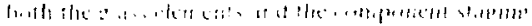

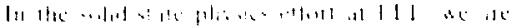

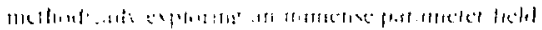

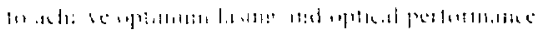

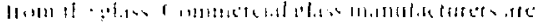

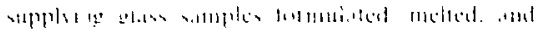

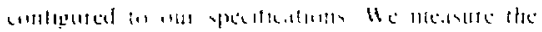

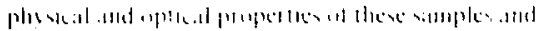

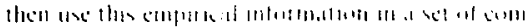

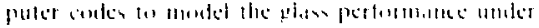

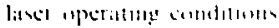

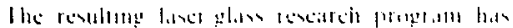

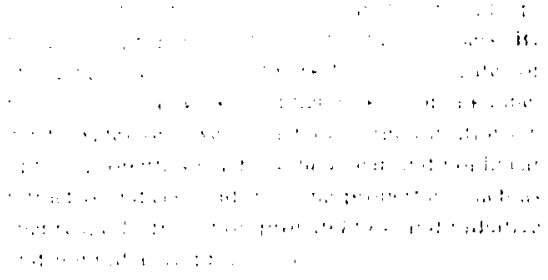

\section{HI HAG:IIVI INGHX}

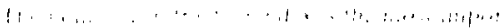

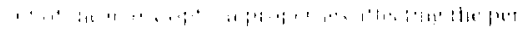

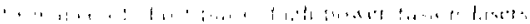

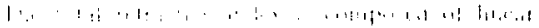

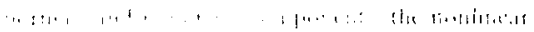

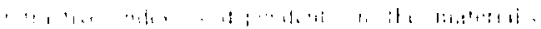

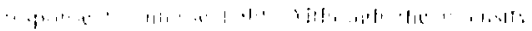

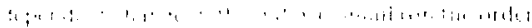

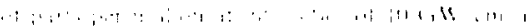

$$
\begin{aligned}
& \text { ! ! . }
\end{aligned}
$$

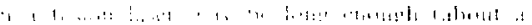

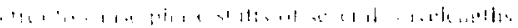

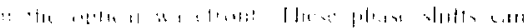

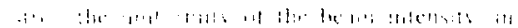

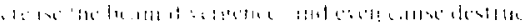

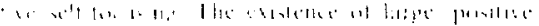

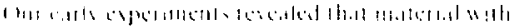

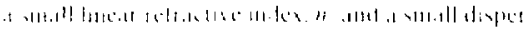

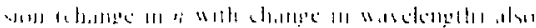

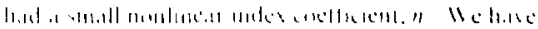

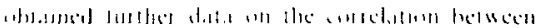

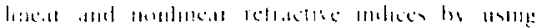

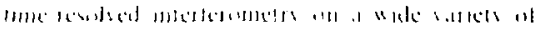

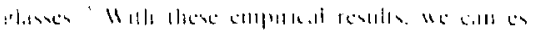

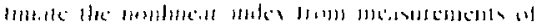

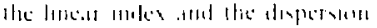

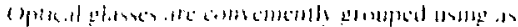

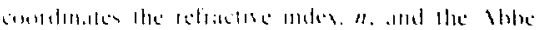

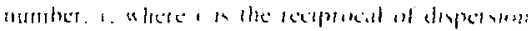

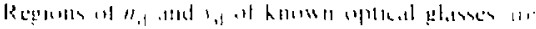

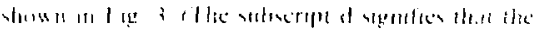

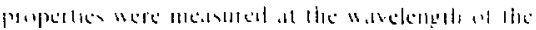


Fig. 3. Optical plasses ot varying componition are mapped by their refractive index and abbe number (reciprocal of dispersion)، Superimposed are dushed line's of cunstunt nunlineur index, $n_{2}$, bused on our measurements. The nonlineur index, $n_{2}$, is reduced on the Moorine-loetexyenen rutios (F/(1) is incruased. The most promising plasses for fusion lasers are thuse ourard the fower lefthund coracr.

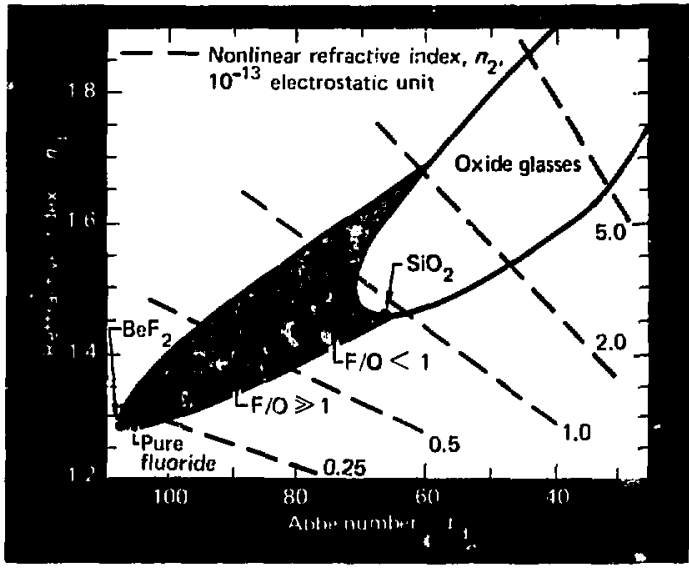

helium $d$ line-587,6 nm.) Superimposed in Fig. 3 are dashed lines of constant $n_{2}$ predieted from the $n_{\mathrm{d}}$ and $v_{\mathrm{d}}$ values. To propagate laser beans with small distortions. we need low-n 2 glasses; these are

Tuble 1. Various types of fluoride-containing glasses. Wo have investigated those marked with an atterisk for possible fusion laser applications.

Pare Fluoride Glases:
Foumer

$\mathrm{BeF}_{2}$

$\mathbf{A I F}_{3}$

$\mathrm{ZrF}_{4}$
Modifier ions

$M F\left(M^{+}=L, N a, K, R b, C s\right)$

$\mathrm{MF}_{2}\left(\mathrm{M}^{2+}=\mathrm{Mg}_{\mathrm{g}} \mathrm{C}, \mathrm{Sr}, \mathrm{Ba}, \mathrm{Z}_{\mathrm{n}}, \mathrm{Cd}, \mathrm{Pb}\right)$

$\mathrm{MF}_{3}\left(\mathrm{M}^{3+}=A 1, \mathrm{Y}, \mathrm{La}, \mathrm{Bi}\right)$

$\mathrm{MF}_{4}\left(\mathrm{M}^{4+}=\mathrm{Zr}, \mathrm{Th}\right)$
Fluorde Glases Contuining Oxygen $\left(\mathrm{F} / 0^{8}>1\right)^{*}$

Ftwordr fawes contuining smalt mole $\%$ phosphate

Oxido Clases Containing Fluorine (F/O $\lesssim$ 1)

Fluoroborite

Futoronicate*

Fluospphosphate*

Fluorcoemninate

"F/O reptesents the ratio of fluorine to oxygen ions. the fluoride-contitining glasses in the lower lefthand corner of the figure. Various types of thooride glasses are listed in Table 1.

The most conmon commercial optical glasses are oxide glasses, principally silicates and phosphates (i.e.. $\mathrm{SiO}_{2}-$ and $\mathrm{P}_{2} \mathrm{O}_{5}$-base). Current optical glasses with the lowest $n_{2}$ values are fluorine-containing oxide glasses, namely, fluorosilicates and Muorophosphites. The glass with the lowest index reported is beryllium fluoride $\left(\mathrm{BeF}_{2}\right)$ without any modiliers. $\mathrm{BeF}_{2}$ forms a glass analogous to $\mathrm{SiO}_{2}$, but it is more ionic and the $\mathrm{BeF}_{2}$ bonds are weaker (therefore, it has a lower melting point). Pure BeF 2 and $\mathrm{SiO}_{2}$ glasses are plotted in Fig. 3 and represent the lowest $n_{2}$ values of the fluoride and silicate glass types, respectively. The addition of network modifiers, such as alkali, alkaline earth. aluminum. and other cations, changes the optical properties and yields the $n_{\mathrm{d}^{-}} \mathrm{d}_{\mathrm{d}}$ regions shown.

Because of their small predicted $n_{2}$ values. fluoride glasses are the most promising candidates for both passive components (such as lenses, windows, and substrates) and active components (such as the laser-amplifier and Faraday-rotation media). Optical figures of merit two to three times that of present oxide laser glasses may be realized (see 
Table 2. Figures of merit for the nonlinear refractive index of optical materials."

\begin{tabular}{|c|c|c|c|c|c|}
\hline Component & $\begin{array}{l}\text { Figure- } \\
\text { of-merit } \\
\text { formula }\end{array}$ & $\begin{array}{c}\text { Silicatc } \\
\text { glass } \\
\text { (ED.2, LSGr-9|h) }\end{array}$ & $\begin{array}{c}\text { Phosphatc } \\
\text { glass } \\
\text { (EV-2, } \\
\text { LHG-7, } \\
\text { Q-88) }\end{array}$ & $\begin{array}{c}\text { Fluoro- } \\
\text { phosphato } \\
\text { glass } \\
\text { (LG-810, } \\
\text { E-181, } \\
\text { LHG-10)b }\end{array}$ & $\begin{array}{c}\text { Fluoro- } \\
\text { beryllate } \\
\text { giass } \\
\text { (B-101)b }\end{array}$ \\
\hline $\begin{array}{l}\text { Leser disk } \\
\text { (parasitic-timited; } \\
\text { it Brewster's andle) }\end{array}$ & $\frac{n^{2}}{n_{2}}$ & 1.0 & 1.4 & 2.3 & 3.1 \\
\hline Window & $\frac{n}{n_{2}}$ & 1.0 & 1.4 & 2.3 & 3.6 \\
\hline lenn & $\frac{n(n-1)}{n_{2}}$ & 1.0 & 1.3 & 2.0 & 2.2 \\
\hline
\end{tabular}

A smalter $\mathrm{n}_{2}$ implies a larger figure of merit and, hence, a better glass. Silicute glasses are currently used In glass Insers at LLL.

'Manufacturer's designation.

Table 2). Since fluoride glasses generally have large band gaps, they transmit light over a large spectral range. Hence they are potentially useful as transmitting optical components for high-power lasers operating at various wavelengths with lasing media other than neodymium.

\section{LASING PROPERTIES}

In the amplifying element. the important factor is the influence of the host glass on the ability of the lasing ion to absorb light from the optical pumping source. 10 store this energy. and to release it to amplify the laser beam. Inergy slorage by the lasing ion is governed by its ab.orption propertics. excited-state lifetimes. and yuantum efficiency. The position of absorption bands of rare-earth ions (such as neodynium) in solids shows little change with host. but the relative strength of the bands does change. Thus, the absorption coefficient of the lasing ions is host-dependent.

lasing ions excited to high-energy electronic states relax non radiatively (heating the host) to the upper lasing energy level. The lifetime of this metastable state 'tetermines how fast the level must be pumped to achieve the excited lasing ion population necessary for lasing.
Also, for tach absorbed pumping photon. one lising photon should ecme out. The quantum officiency can be degraded in sone hosts if the ionhost interastion caluses non radiative losses. In addjtion, interactions between lasing ions can also cause self-quenching. This elfect limits the useful dopant concentration in the glass: that is, the lasing ion concentration cannot be arbitrarily increased without causing sell-deftating losses. Thus. the important parameters of net absorption, rate o excit* tion. and efficiency are all dependent on the host glass.

The rate of energy yield from a laser amplifier is governed by a product of the optical intensity of the extracting beam and the stim ilated emission cross section of the lasing ions. As diseussed earlier, the beam intensity is limited by the nonlinear refractive index of the host glass. The stimulated enission cross section is also nost-dependent.

The emission cross section of a lasing ion determines the yield of the stored energy and, thus, the amount of its amplification. The best cross section to use depends on the intended operation of the laser. Short-pulse, unsaturated lasers need highcross-section materials in order to get large gain coefficients with a minimum thickness of glass. 
However, if the cross section is too high. parasitic losses (in large amplifiers) and saturation will set in and limit performance. On the other hand, longpulse. saturated lasers require low cross sections so that large amounts of energy can be stored and extracted withoul parasitic losses. The cross section must not be too low because excessive flux, capable of causing nonlinear optical distortion, would be reyuired to extract the energy. For any fixed pulse width, there is an optinum cross spetion. If the cross section is too low, gain is low and too much material (glass) is required in the beam path. If the cross sect $n$ is 100 high, saluration and parasitic losses reduce the gain. The optimum eross sertion generally becomes snlaller us the pulse width is increased.

The ideal glass is one for which the emission cross section can be varied by a variation in glass composition without degradation of other desirable properties. However, some interation is unavoidable: for example, raising the cross section usually increases the nuoreseent decay rate. Farly studies have shown that in silicate glasses, variations by a factor of three in the cross section were possible by changing the network-modifier ions. Variations in cross section by a factor of five have been observed by varying gliss network formers. 4

An additional consideration is the lerninal laserlevel decity time. To extract all of the stored energy, the terninal laser state musi rapidly relax to the ground state. If the stimulated emission rate is 100 fast, bottlenteking oceurs at the terminil energy level, which reduces the useful energy yield. The relaxation rate of the terminal level is also governed by jon-host interactions and can be varied by selecting different glass compositions.

Different glasses may be optimum for different anplifier stages for reisons other than optimun gain. But the wavelength of peak gaitt varics with the glass used. In the cise of phosphate and fluorophosphate glasses, the wavelength differences of the two glasses are small, and their use can he mixed without a large sicrilice in gain performance. This statemem is not Irue, however, for the combined use of, say, silicate and phosphate glasses or oxide and fluoride glasses. Nor does it apply to passive components.

rable 3 "smpares the range of spectroscopic properties observed in different glass types of inlerest. A wide variation in most paramelers hats been oblained and thus provides the laser denigner with a range of matcrial paramelers io select in op. limizing a latser design.

\section{LASER-GLASS OPTIMIZATION STUDIES}

Since the advent of lasers, thousiands of glatsses have been formulated to invertigate the elfects of changes in glass network and network-modilier ions on the spectroseopic and lasing paramelers of neodymium. This work to a latge degree wis empirical and was hampered hy two defficulties: first. the spectroscopic properties and interictions of rare-earth ions were not completely understood evell in a erystal environment: second, llue specilice uses and applications of lasers were less well defined and. therefore it wiss not always clear which properlies should be optimiated. Today, both of these problem areals are heller understond, and we have

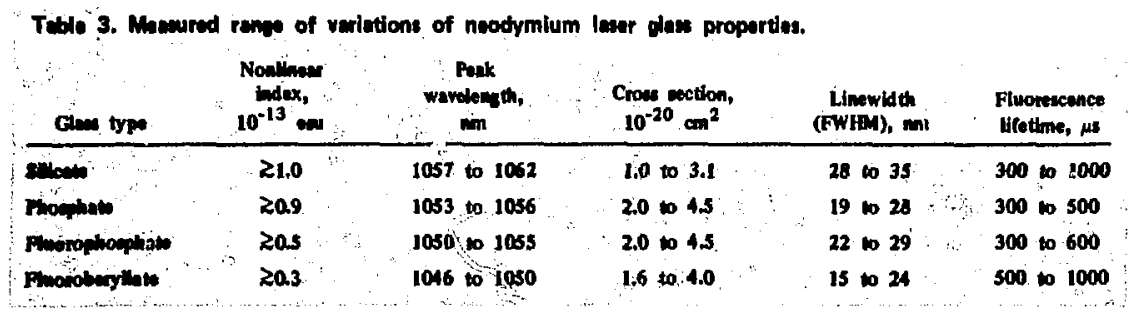




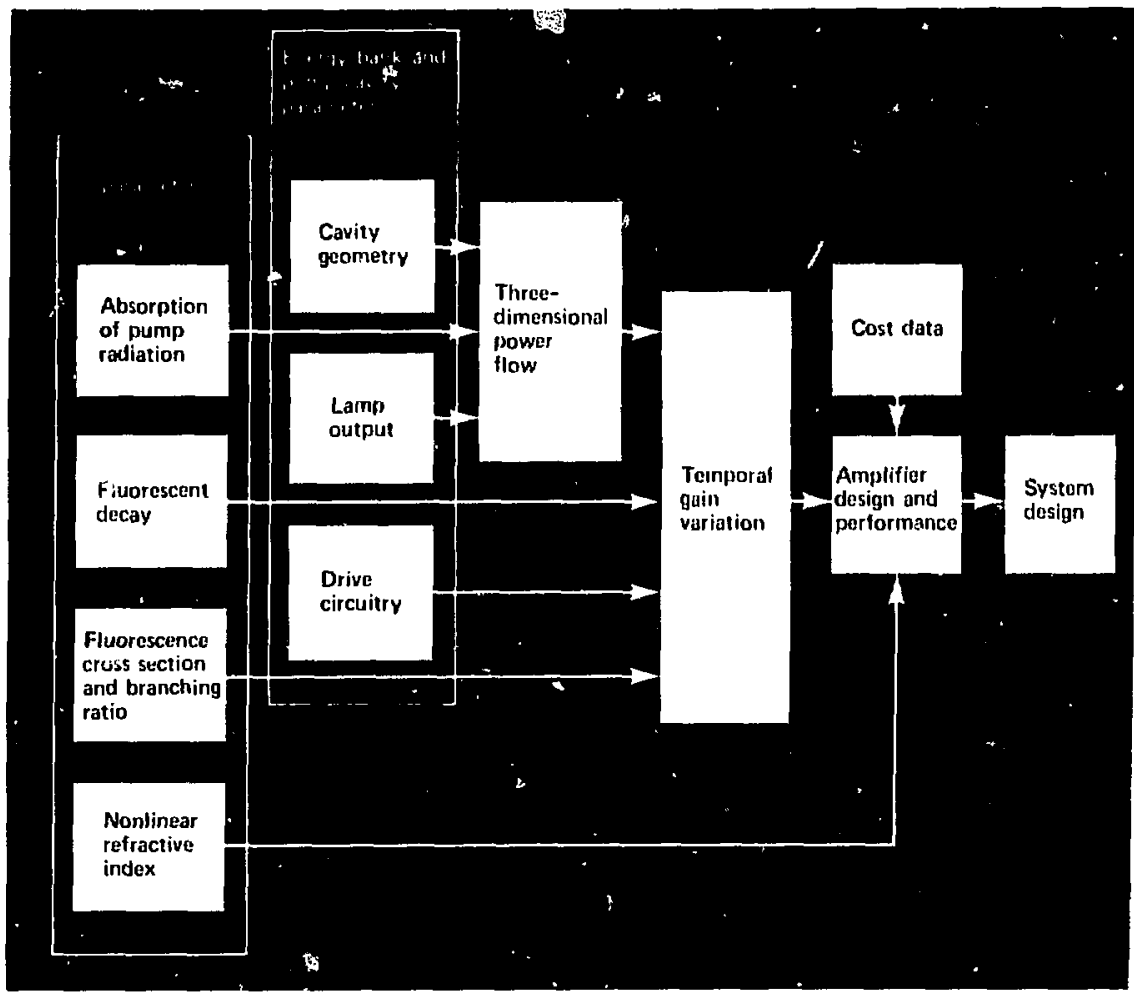

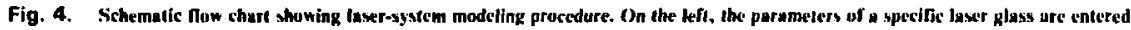
into uppropriate glass-modeling codes. The next block provides detuled informution on the cupucitor hunk, laser heuds, reflectors, Dashlumps, and lamp circuitry, which input to the uppropriate codes for modeling the power now and guin variution. 'The final rexult of this modeling is the most custeffectine laser systen design.

now evalualed over 200 glasses for fusion laser applications.

Predictions of the small-signal laser gain are based on measurements of absorption and fluoreseence spectra and decay properties combined with calculations of the eflects of flashlanip pumping. We have been successful in using data ubtained from small glass melts to:

- Determine lasing parameters from spectroscopic properties.
- Istimate the nonlinear reliactive index from linear refractive indices.

- Predict gatin of amplitier stages and model the most cost-wfective staging of an overall laser syslem.

From such work, the optimum glasses are stiected for the design and staging of individual laser amplifiers in an overall fusion laser system. The lowest-cost system is then chosen for comparison or implementution. 
A llow thart for modeling amplifier performance is shown in Fig. 4. The ahsorption spectrum of the candidate glass is recoided from the near-ule raviolet 10) the near-infrared. Using the measured line strengths, we derive a set of oprical intensity paraincters to calculate fuorescence line sirengths and to determine the stimulated emission cross section. We also calculate the radiative lifelime and conpare it with the cobserved fluoresenese desay rate to determine the quantum efficiency. With ditit from the per-ion absorption spectrum, a compuler pregram calculates the fractionial absorption by the materiat of the xenon fishlasmp radiation. The program contasins a model of the llashlamp output spectrum that we modilied by rerunning soms of the light back through a layer of platsmat lo approxumale the multiple passes that actually oceur inside the laser pumping eavity. We then use the output eurves

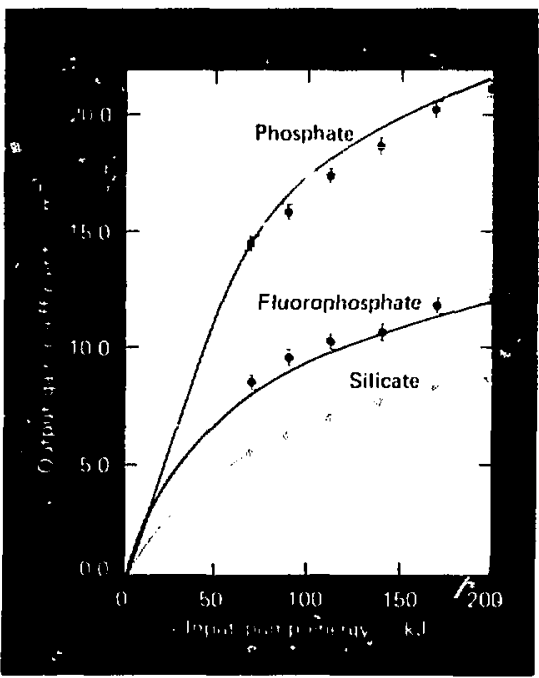

Fig. 5. Comparison of measured (points) and catculated (lines) gain coefficients for three neodymium glasses, using the laserglass modeling procedure shown in Fïg, 4 . With all other condjtions the same, the mere change to phosphate or fluorophosphate giasses will markedly increase the laser gain or provide the advantage of a much smrller nonlinear index of refraction. of fractional absorption ats a function of opteal depth in conjunction with decay rate and cross section information to predict the temporal gain of dif. ferent malterials in disk laser amplifiers.

How well does this work? Higure 5 shous the laser amplifier output vezsus pump energy input for threc glasses: a high-gain phosphale. a fluorophosphate, and a low-gain silicate. Shown are a comparison al measeased points and predicted

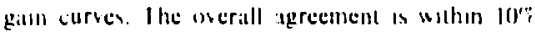

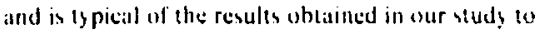
date. Hetaluse of uncertianties no the accuratey of modeleng the pump tavity conliguration. dats on as silicale glass are normalired to the predictions: however, ance this arrmalization hat taken plate. there are no wher adjustable parameters.

\section{PROGRAM STATUS AND PLANS}

Signilicantly improved neodymium-glass lasier perlormance is now pussible with newly developed glasses. We hate found that lor short-pulse, highpower lasers, the output is neirly inversely proportional to the nonlinear refractive index of the glass. $n_{2}$. (ilisses with $n_{2}$ from ont-half (t) one-third lower thitn presently used glasses have been identified. The relative figure of neril of these glass:s for several iaser elements is given in Table 2. In atddition, by using phosphate rather than silicate glasses, we have achieved amplifier gain increases greater than $50 \%$.

Commercially available phosphate glasses can have very high gain. but their use in large disk amplifiers is limited because high-gitin-induced parasitic losses become dominant. For these large amplifiers. lluorophosphate glasses with mediumhigh gain and low $n_{2}$ are currently the best choice and are the most likely medium for the next larger Nd-glass laser system at LLL (see fig. 5). The predicted performance of this laser. which we call Nova. is based on the physical parameters of the glasses. Undoped Muorophosphate glasses have been commerciully available for some time and are now being formulated and optimized for use in fusion lasers. Beryllium fluoride glass, the ultimate high-power laser medium, is being formulated and tested in small quantitiec; test results have been very 
encouraging. but great uncertainties remain in the production of lacge, high-optical-quality pieces and in the yields and costs associated with the precalulions of handling beryllium.

To ensu: that improved glasses will be available in (iine for Nowa, H:RDA is supporting developmental research with glass manufacturers in close cooperation with L.I.l. Nen glasses are being evaluated in our computer-equipped spectrosiceny laboratory" where more than a doren spectroscopic. optical. and physical properties are measured on samples supplied by manufacturers. To hasten development. we provide this information to the manufacturers in the form of data books - to date, in six volunes describing about 200 laser glasies. I.arge melts of fluorophosphate laser glasses are now being cast into test disks for Nova protolype components.

New ideas in laser design indicate that 10-MJ. 1000-TW solid-state liser systems may be possible. Recent studies also point toward high-averagepower systems with efficiencies greater than $1 \%$. These concepts are optimistic, but they may be more reasonable extensions of established glass laser tecbnology than we presently imagine. The accomplishment of laser fusion objectives with advanced lasers based on gaseous laser media will also require imaginative use of optical materials. These lasers are limited by nonlinear, damage. and manufacturing constraints just as solid-state lasers have been. Materials similar to those described in this report will be the basis for the design of future high power lasers.

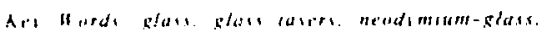
tavera-materials

\section{NOTES AHO REFERENCES}

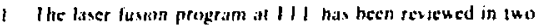

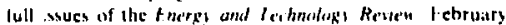
1976 (1'( R1 -520(7).76-2) and August 1977 ( $($ ic RL. -5200$)$ 77.9) More delasled information on the program in presen-

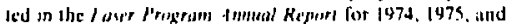
1476. I awrence I wermare I ahasistory. Repts I'CRI.

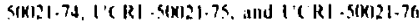

2 11 J Weher. "(1)ptical Vaterials for Neutymtum I-usun

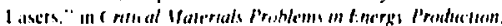

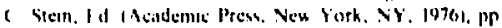
$2(1,-273$

3 I S Bliss, I) R Speck, and II W Stmmens, "Inreer Inter. fermmetre Measurements of the venlmetar Refractive Index

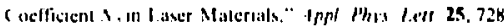
(1974); (1). Milian and M. J. Weber, "Neasurement of Nonlineatr Relsative-Index Coeflicients Llsing Time-Hesolved Interferometry: Applicituon to Optutil Materials for JighPower Neodymium l.axers." I . Inpl Phar 47. 2497 (1976): and "Vinlineir Refrestive Index Coefficient for $\mathrm{Nd}$

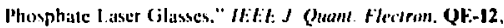
$512(1976)$.

4. R. R. Jacobs and M. J. Weber. "Dependence of the H: "

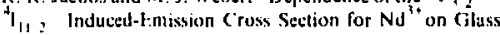
Composition." HEEEI Quamt HEetrm. QH.12, 102 (1976).

5. Fon a description of the computer-equipped spetroscopy laboratory, see R. A. Saroyan and M. J. Weher, inconcentional Spectroscopl: procesdings of a echniabl symposium held in Sin Dicgo, Calif., August 24-25. 1976 (SPIE. Palos Verdes Estates, Caljf., 1976), vol. B2, П. 165.

6. (i. J. Linford, R, A. S.ıruyan, J, B. Trenholme, and M. J. Weber. "Measurements and Modeling of Gain Coefficients for Neodymium Glass Lascrs," Digest of Technical Papers. 1977 IE:E $/ O S A$ Conference on Laser Engineering and $\Lambda$ plicutions. Washington. D.C.. June I-3 (to be puhlished). 


\section{PAST TITLES}

Articles in the I.nergy and Techmology Review have been organized into subject areas approximately corresponding to the Assistant Administrators arcas of responsibility in the Energy Research and Development Administration. These subject areas are listed below with references to some recent articles in each calegory. (A semiannual index appears in the June and December issues)

\section{CONSERVATION}

Car for Tomorrow: A Quasi-Flectric-Drive Vehicle (Iune 1977)

Transportation's Role in the Energy Problem (March 1977)

The Methanol fingine: A Transportation Stralcgy for the Post-Petroltum lifa (December lyit)

\section{ENYIRONMENT AND SAFETY}

Diagnosing Cervical Cancer with Flow Cylometry (./uly 1977)

Phantom Construction: Building a Torso Manikin for Whole-Hody (ounting (December 1976)

Getting the Jacts About Orone (November 1976)

\section{FOSSIL ENERGY}

Progress in Oil-Shale Research (February 1977)

Hoe Creek No. I An In Situ Coal Gasification Experiment (Jomuary 1977)

\section{LABORATORY TAENDS}

Continuing Education at I.L.L. (M/ay 1977)

The I.aboratory: Retrospect and Prospect (February 1977)

Achievemenis and Developments at LLL. (Fehruary 1977)

\section{NATIONAL SECUAITY}

The Livermore Pool-Type Reactor (Jume /977)

Imaging Implosion Dynamics: The X-Ray Pinhole/Streak Camera (December 1976)

\section{NUCLEAR ENEAGY}

Western States Uranium Resource Survey (May 1977)

\section{PHYSICAL SCIENCES ANU ENGINEERING}

Probing Nuclei with L.L.'s Electron Linear Accelerator (/uly 1977)

Mapping Underground Structure with Radio Waves (Jamuary 1977)

DISPLAY: An Interactive Picture Editor (Jamuary 1977)

\section{SOLAR, GEOTHERMAL, AND ADVANCED ENERGY SYSTEMS}

Laser Fusion Prog-am Overview (August 1977)

Taming Geothermal Brines for Electrical Power (Jwly /977)

TMX: A New Fusion Plasma Experiment (July 1977)

Wind-Energy Assessment (June /977) 


\section{NOTICES}

This repurt was prepared as an account of work sponsuied by the Uniled States Guvernment. Neitlet the Uniled Stales not the United States Inetgy Research \& Development A Jministration, nor any of their employecs, nor any of their contractors, subcontrsctors, of theis employexs, makes any wartanty, express or implicd, or assumes any legal liability of tesponsibility for the acturacy, eompleteness or usefulness of any information, apparatus. product or process disclosed, or represents that its use would not infringe privately ow ied rights.

Reference to a company or producl name does not imply approval or recomnendation of the product by the University of Califurnit or the U.S. Iinctgy Ressurtl \& Development Administration to the exclusion of others that may be suitable.

Printed in the United States of America Available from

National Technical Information Service

U.S. Department of Commerce 5285 Port Royal Road

Springficld, Virginie 22161

Price: Printed Copy $\$ 4.00 ;$ Microfiche $\$ 3.00$ 


\section{PAST TITLES}

Articles in the Energl and Technology Review have been organized into subject areas approximately corresponding to the Assistant Administrators' ureas of responsibility in the Energy Research and Development $A$ dministration. These subject areas are listed below with references to some recent articles in each category. ( $A$ semiannual index appears in the June and December issues.)

\section{CONSERVATION}

Car for Tomorrow: A Quasi-Electric-Drive Vehicle (Jute 1977)

Transportation's Role in the Energy Problem (March 1977)

The Methanol Engine: A Transportation Strategy for the Post-Petroleum Era (December 1976)

\section{ENVIRONMENT AND SAFETY}

Diagnosing Cervical Cancer with Flow Cytometry (/fily /977)

Phantom Construction: Building a Torso Manikin for Whole-Body Counting (1)ecember 1976)

Getting the Facts About Ozone (November 1976)

\section{FOSSIL ENERGY}

Progress in Oil-Shale Research (February 1977)

Hoe Creek No. l: An In Siru Coal Gasilication Experiment (Jamuary 1977)

\section{LABORATORY TRENDS}

Continuing Education at LLL (May 1977)

The Laboratory: Retrospect and Prospect (February 1977)

Achievements and Developments at LLL (February 1977)

\section{NATIONAL SECURITY}

The Livermore Pool-Type Reactor (June 1977)

Imaging Implosion Dynamics: The X-Ray Pinhole/Streak Camera (December 1976)

\section{NUCLEAR ENERGY}

Western States Uranium Resource Survey (Mfay 1977)

\section{PHYSICAL SCIENCES AND ENGINEERING}

Probing Nuclei with LLL's Electron Linear Accelerator (July 1977)

Mapping Underground Structure with Radio Waves (January 1977)

DISPLAY: An Interactive Picture Editor (Jantuary 1977)

\section{SOLAR, GEOTHERMAL, AND ADVANCED ENERGY SYSTEMS}

Laser Fusion Program Overview (August 1977)

Taming Geothermal Brines for Electrical Power (/u/y 1977)

TMX: A New Fusion Plasma Experiment (July 1977)

Wind-Energy Assessment (June 1977) 


\section{NOTICES}

This repost was prepared as an atcount of work sponsored by the United States Government. Neither the United States not the United Stutes Finctgy Ressarch \& Developirient Administration, nor any of their employecs, nor any of their contractors, subcontractors, or their employees. makes any waranty, express or implied, or assumes any legal liability or responsibility for the accuracy, coinpleteness or usefulness of any information, apparatus, produel or process disclosed, or represents that its use ivould not infringe privalely owned $t$ ights.

Reference to a company or product name does not imply approval or recommendation of the product by the University of California or the U.S. Enutgy Research \& Development Administration to the exclusion of others that may be suitable.

\section{Printed in the United States of America Available from}

National Technical Information Service

U.S. Department of Commerce

S285 Port Royal Road

Springfield, Virginia 22161

Price: Printed Copy \$4.00; Microfiche $\$ 3.00$ 